NBER WORKING PAPER SERIES

\title{
FACTS AND CHALLENGES FROM THE GREAT RECESSION FOR FORECASTING AND MACROECONOMIC MODELING
}

\author{
Serena $\mathrm{Ng}$ \\ Jonathan H. Wright \\ Working Paper 19469 \\ http://www.nber.org/papers/w19469
NATIONAL BUREAU OF ECONOMIC RESEARCH
1050 Massachusetts Avenue
Cambridge, MA 02138
September 2013

We are grateful to Frank Diebold and two anonymous referees for very helpful comments on earlier[versions of this paper. Kyle Jurado provided excellent research assistance. The first author acknowledges【financial support from the National Science Foundation (SES-0962431). All errors are our sole responsibility.The views expressed herein are those of the authors and do not necessarily reflect the views of the National Bureau of Economic Research.

At least one co-author has disclosed a financial relationship of potential relevance for this research. Further information is available online at http://www.nber.org/papers/w19469.ack

NBER working papers are circulated for discussion and comment purposes. They have not been peerreviewed or been subject to the review by the NBER Board of Directors that accompanies official NBER publications.

(C) 2013 by Serena Ng and Jonathan H. Wright. All rights reserved. Short sections of text, not to exceed two paragraphs, may be quoted without explicit permission provided that full credit, including (C notice, is given to the source. 
Facts and Challenges from the Great Recession for Forecasting and Macroeconomic Modeling Serena $\mathrm{Ng}$ and Jonathan $\mathrm{H}$. Wright

NBER Working Paper No. 19469

September 2013

JEL No. C22,C32,E32,E37

\title{
ABSTRACT
}

This paper provides a survey of business cycle facts, updated to take account of recent data. Emphasis is given to the Great Recession which was unlike most other post-war recessions in the US in being driven by deleveraging and financial market factors. We document how recessions with "financial market origins are different from those driven by supply or monetary policy shocks. This helps explain why economic models and predictors that work well at some times do poorly at other times. We discuss challenges for forecasters and empirical researchers in light of the updated business cycle facts.

\author{
Serena $\mathrm{Ng}$ \\ Department of Economics \\ Columbia University \\ 440 W. 118 St. \\ International Affairs Building, MC 3308 \\ New York \\ NY 10027 \\ serena.ng@columbia.edu \\ Jonathan H. Wright \\ Department of Economics \\ Johns Hopkins University \\ 3400 N. Charles Street \\ Baltimore, MD 21218 \\ and NBER \\ wrightj@jhu.edu
}




\section{Introduction}

In 1985, Victor Zarnowitz wrote a paper in the Journal of Economic Literature that provides historical background on business cycles and outlines the evolution of thought leading to developments in theory and related empirical evidence (Zarnowitz, 1985). Prior to that writing, the dominant view had been that the business cycle reflected stationary deviations around a deterministic trend attributed to exogenous growth, and that business cycles were all alike in the sense of having many common features. When Zarnowitz wrote his paper, the economy had just emerged from the longest post second world war contraction, preceded by a string of supply shocks with severe inflationary consequences that made economists and econometricians reconsider the adequacy of their assumptions and tools used to analyze business cycles.

Over twenty-five years have passed since the paper was published and there have been developments in several dimensions. Supply shocks of the 1970s contributed to level and trend shifts of many economic variables, making economists rethink whether the trend stationary paradigm is the appropriate characterization of economic data. At the econometric level, it is now more or less accepted that many economic time series are difference stationary, and occasional mean shifts, parameter instability, stochastic volatility, and common trends are features that need to be considered. Statistical tools are now able to take advantage of the increasingly data-rich environment so that analysis of economic fluctuations and growth can exploit information from a broad spectrum of the economy. Data from different sources and frequencies can be analyzed within the same framework. Our understanding of data revisions has expanded, permitting a better understanding of decision-making in real time. We can also nowcast, a methodology for "predicting" the current state of the economy, taking into account incoming news announcements as well as special factors such as strikes and hurricanes. ${ }^{1}$

There have also been important advances in macroeconomic analysis. Models with tight microfoundations are now the standard starting point of understanding business cycle dynamics, replacing large scale models that are not fully internally consistent. In these dynamic stochastic general equilibrium (DSGE) models, fiscal, monetary, preference and supply shocks are propagated and amplified by intertemporal decisions of households and firms made under misperceptions, incomplete information, real and nominal rigidities. Statistical and

\footnotetext{
${ }^{1}$ For analysis in a data rich environment, see Bernanke and Boivin (2003), Stock and Watson (2006). For real time analysis, see Croushore (2011). For nowcasting, see Evans (2005), Giannone, Reichlin, and Small (2008), among others. Faust and Wright (2009) argue that most or all of the information content of the Greenbook and other judgmental forecasts for economic activity seems to come from their nowcasting ability.
} 
computational advances now make it possible to take moderate size models to the data so that formal model validation is possible. ${ }^{2}$

While advances in econometric and macroeconomic theory have helped us better understand events that were important in 1985, the facts have changed since. There has been a secular increase in the share of services in consumption from an average of $50 \%$ before 1983 to $65 \%$ after 2007, at the expense of non-durables (from $35 \%$ to $22 \%$ ). Labor share in the non-farm sector has fallen, as has the share of manufacturing employment. The civilian labor force participation rate stands at $63.5 \%$ in 2013 , much below the peak of $67.2 \%$ in 1999 . This is in spite of female participation rate rising from under 35\% in 1945 to over $60 \%$ in 2001, as the male participation rate has been falling since 1945. The US economy also experienced increased openness; international trade and financial linkages with the rest of the world have strengthened, with the volume of imports plus exports rising from 12\% of GDP before 1983 to $27 \%$ post 2007 . Meanwhile, not only have households' and firms' indebtedness increased, so has foreign indebtedness. For example, the household debt-to-asset ratio rose from under 0.75 in the 1950 s to over 1.5 in 2000 and has increased further since. Net external assets relative to GDP have also risen from 0.82 in the 1970 s to 2.4 when the sample is extended to $2007 .^{3}$ One of the most important changes was the sharp reduction in volatility of consumption, investment and output growth between the mid 1980s and 2006, a phenomenon referred to as the Great Moderation. This was first documented by Kim and Nelson (1999) and McConnell and Perez-Quiros (2000), and subsequently confirmed by others.

The aforementioned changes in the data since 1985 are overshadowed by the sharp decline in economic activity that began in 2007, followed by a recovery that is in many ways still incomplete, as real GDP per capita in 2012 remained lower than its level in $2007^{4}$. This Great Recession is important not only because of its impact on the economic well-being of consumers and firms, but also because it once again led econometricians and macroeconomists to question the adequacy of their analysis. In conventional business cycle analysis, emphasis is placed on the fluctuations of macroeconomic variables alone. Asset prices, financial variables and the financial system are a side-show. Yet, as noted by Minsky (1986) and Sinai (1992), financial market factors can be the primary causes of downturns. And indeed, one only needs to look at the Great Depression for evidence; it began with the stock market crash in 1929, and led to debt deflation and bank runs in the years that followed. Nonetheless, there was a broad lack of interest in business cycles of financial origins, the most likely reason being that US recessions in the 1970 s and 80 s can be traced to supply and demand shocks of the

\footnotetext{
${ }^{2}$ See An and Schorfheide (2007) and Fernández-Villaverde (2010).

${ }^{3}$ Consumption and manufacturing data are taken from FRED. For domestic debt, see for example, FRBSF Economic Letter January 2011. For foreign debt, see the database of Lane and Milesi-Ferretti (2007).

${ }^{4}$ Source: NIPA Table 7.1.
} 
monetary/fiscal policy type, with financial factors merely amplifying the shocks. But the role of financial markets in recent business cycles can no longer be seen as passive. Though the recessions of 1990-1991 and 2001 were mild and brief, they had financial origins, with roots in the savings-and-loan crisis and the internet bubble, respectively. These two recessions did not lead to serious problems of financial market functioning. It was however the breadth and depth of the Great Recession, which involved a full-blown financial crisis, that brought the role of financial markets back to center-stage of business cycle analysis.

This paper takes an overview of the facts and explanations of recent recessions from the perspective of macroeconometricians and is very much in the spirit of Zarnowitz (1985). We review the business cycle literature, update the stylized facts and summarize the economic theories that purport to explain those facts, but with emphasis on the post 1985 sample and on features of recessions with financial market origins. The discussion is organized to achieve three objectives with the linkages between finance and the real side of the economy as the focal point. The first is to document the changing time series properties of the data using factor analysis to give new perspectives on the nature of these changes, and giving attention to volatility dynamics that was absent in Zarnowitz (1985). The second objective is to examine the particular role that financial frictions, leverage and uncertainty played in recent economic fluctuations, and especially the Great Recession. We study evidence on economic downturns that are rooted in asset and financial markets, highlighting features that are different from recessions that are due to adverse supply or demand shocks. Our third objective is to take an overview of the effectiveness of our econometric methodology in light of the experience of the recent recessions.

An overview of the updated business cycle facts is that while there are broad similarities, recessions that originate with financial market dislocations are distinctively different from those in which financial markets play a passive role. Recoveries are slow when the recessions have financial origins, especially in resuming the flow of private credit and moving the unemployed back to work. That financial and non-financial business cycles have different theoretical implications is not surprising, but that these differences are empirically relevant confront policy makers, macroeconomists, and econometricians with new challenges. Our discussion centers on the econometric issues relating to macroeconomic forecasting, estimation of turning points, and identification analysis.

Numerous surveys of business cycle theory and facts are available since Zarnowitz (1985) using data updated to around 2000. Diebold and Rudebusch (1996) relate the factor structure in the data and the property of regime switching to macroeconomic models with spillovers and strategic complementarities. King and Watson (1996) study the relation between money, prices and interest rates over business cycles and assess the adequacy of sticky price and 
liquidity effect in explaining the facts. Diebold and Rudebusch (1999) discuss issues relating to the measurement, modeling, and forecasting of business cycles. Stock and Watson (1999) document the time series properties of the data at business cycle frequencies while Stock and Watson (2002b) consider the causes of the Great Moderation. Christiano and Fitzgerald (1998) suggest a new business cycle filter and document sectoral comovements of hours worked at the business cycle frequencies, arguing that shifts in expectations triggered by strategic complementarities, information externalities, and efficiency wage theory can explain the facts. However, these papers all preceded the Great Recession. We start where others left off.

The plan for the remainder of this paper is as follows. Section 2 discusses business cycle facts. Section 3 uses tools of factor analysis to understand comovement and volatility of a wide range of macro time series. Section 4 discusses the Great Recession specifically. Sections 5 and 6 examine challenges for forecasting and structural identification analysis, respectively. Section 7 concludes.

\section{Business Cycle Facts}

We are interested in business cycle fluctuations as opposed to movements in secular trends. A business cycle is generally understood to consist of fluctuations in economic activity characterized by at least two distinct states - expansionary and contractionary. Formal quantitative analysis of business cycles began with the seminal work of Burns and Mitchell (1946) who developed rules to determine the phase and amplitude of cycles upon studying data on employment, production, prices and other macroeconomic aggregates. These procedures still guide the National Bureau of Economic Research (NBER) Business Cycle Dating Committee, the authority in dating US recessions. The committee defines a recession as a period of falling economic activity normally visible in real GDP, real income, employment, industrial production, and wholesale-retail sales spread across the country. Note that no reference is made to money and credit markets, and only domestic economic conditions are considered. In empirical work, a recession has also been defined as two consecutive quarters of decline in real GDP growth, or a 1.5\% rise in unemployment within twelve months, but these definitions apply exclusively to non-financial, country-specific variables.

The NBER's definition of a U.S. recession is quite flexible and relies on the judgment of the committee members. They measure the duration of a recession by the time elapsed between a peak and a trough, while an expansion is the period from a trough to a peak. A full business cycle is defined from one trough to the next. While the NBER business cycle dates are widely accepted as the benchmark, the committee tends to announce the beginning 
and end of recessions well after the fact. This motivates the development of procedures to identify business cycles and their turning points in a more mechanical and timely manner (Chauvet and Hamilton, 2006; Stock and Watson, 2010). More on this in subsection 5.2 below.

Zarnowitz (1985) analyzed the characteristics of business cycles from 1854 to 1982 using the NBER dates and showed that there is significant variation in duration and phase. In the period from 1960-1983 that Zarnowitz analyzed, consumption, investment and output expanded rapidly but were quite volatile. Real wage growth was positive. Inflation was elevated (especially in the 1970s and early 1980s), but also variable and persistent. The updated NBER business cycle dates are given in Table 1.

Table 1: Recent NBER Business Cycles

\begin{tabular}{|c|c|c|c|c|c|}
\hline \multicolumn{2}{|c|}{ "Business Cycle Reference Dates } & \multicolumn{4}{|c|}{ Duration in Months } \\
\hline Peak & Trough & \multirow{2}{*}{$\begin{array}{c}\text { Contraction } \\
(\mathrm{P} \text { to } \mathrm{T})\end{array}$} & \multirow{2}{*}{$\begin{array}{c}\text { Expansion } \\
(\mathrm{T} \text { to } \mathrm{P})\end{array}$} & \multicolumn{2}{|c|}{ Cycle } \\
\hline \multicolumn{2}{|c|}{ Quarterly dates are in parentheses } & & & $(\mathrm{T}$ to $\mathrm{T})$ & $(\mathrm{P}$ to $\mathrm{P})$ \\
\hline January 1980(I) & July 1980 (III) & 6 & 58 & 64 & 74 \\
\hline July 1981(III) & November 1982 (IV) & 16 & 12 & 28 & 18 \\
\hline July 1990(III) & March 1991(I) & 8 & 92 & 100 & 108 \\
\hline March 2001(I) & November 2001 (IV) & 8 & 120 & 128 & 128 \\
\hline December 2007 (IV) & June 2009 (II) & 18 & 73 & 91 & 81 \\
\hline \multicolumn{6}{|l|}{ Average, all cycles: } \\
\hline 1854-2011 (33 cycles) & & 16 & 42 & 56 & 55 \\
\hline 1854-1919 (15 cycles) & & 22 & 27 & 48 & 49 \\
\hline 1919-1945 (6 cycles): & & 18 & 35 & 53 & 53 \\
\hline 1945-2011 (11 cycles) & & 11 & 59 & 73 & 66 \\
\hline
\end{tabular}

Table 1 shows that from the early 1980s until 2007, economic growth in the US was more stable than at any point in prior history, with only two mild and short recessions. Overall, the post second world war (WW-II) recessions lasted for a bit less than one year on average while the post WW-II expansions averaged just short of five years. The average duration of the 11 business cycles since WW-II has increased as a consequence of longer expansions.

Even in early work by Burns and Mitchell (1946), it was observed that there is a tendency for the data to behave differently during downturns and upturns. The feature can arise in economic models because of asymmetric temporary shocks as in the plucking model of Friedman $(1969,1993)$, or through the asymmetric price adjustment mechanism as in Tobin (1972). It is now generally accepted that non-convexities of some sort will generate asymmetric model dynamics. Neftci (1984) developed a test of whether contractions are indeed steeper than expansions and found evidence in support of asymmetry. 
Observing that the data are not well characterized by linear models if business cycles are asymmetric, Hamilton (1989) proposed using Markov switching models in which the parameter values alternate between two different states. Strong evidence for the existence of these distinct states is provided in Hamilton $(1989,1995)$. Hamilton's two-state Markov switching model has been generalized to allow transition probabilities to be endogenous and to allow for more states. Sichel (1994) argued for three-state business cycle models (recessions, high-growth recoveries and mature expansions). Sichel (1994) documented the high-growth recovery phase and attributed rapid recoveries from recessions to firms building up inventories in anticipation of stronger final demand. Table 2 reports the average growth rates of GDP in the quarters before business cycle peaks (top panel) and in the quarters after business cycle troughs (bottom panel). Indeed, up until the mid 1980s, the quarters after business cycle troughs tended to be characterized by unusually fast growth. Also, while it's not as strong an empirical regularity, the last few quarters before business cycle peaks appear to be characterized by slightly slower growth. Nalewaik (2011) referred to this as a stall speed phenomenon.

Table 2: Average Growth in Quarters Before Peaks and After Troughs

\begin{tabular}{c|cccccccc}
\hline \hline & \multicolumn{8}{|c}{ Quarters Before Peaks } \\
\hline & 8 & 7 & 6 & 5 & 4 & 3 & 2 & 1 \\
\hline 60Q1-83Q4 & 2.50 & 8.45 & 6.38 & 2.58 & 3.71 & 4.91 & 4.02 & 1.54 \\
84Q1-12Q4 & 2.37 & 4.71 & 3.41 & 3.46 & 2.41 & 3.30 & 2.12 & 2.51 \\
60Q1-12Q4 & 2.45 & 7.05 & 5.27 & 2.91 & 3.22 & 4.31 & 3.48 & 1.82 \\
\hline & \multicolumn{7}{c}{ Quarters After Troughs } \\
\hline & 1 & 2 & 3 & 4 & 5 & 6 & 7 & 8 \\
\hline 60Q1-83Q4 & 6.79 & 6.89 & 4.40 & 6.30 & 3.70 & 3.19 & 3.02 & 3.52 \\
84Q1-12Q4 & 2.22 & 2.43 & 2.46 & 2.71 & 2.66 & 3.37 & 3.87 & 2.45 \\
60Q1-12Q4 & 5.08 & 5.22 & 3.68 & 4.95 & 3.31 & 3.25 & 3.34 & 3.12 \\
\hline \hline
\end{tabular}

Notes: Average annualized real GDP growth in the quarters before/after NBER-dated business cycle peaks/troughs, respectively. The average growth rate of GDP over the full sample was 3.13 percent.

\subsection{Five Differences in the Three Recessions After 1985}

Business cycles of the 1970s and early 80s are widely believed to be due to supply shocks and/or monetary policy. In this section, we highlight five differences in the last three recessions. 
(i) Long but weak expansions:

The 1983-2012 expansions were unusually long, lasting an average of 95 months compared to 46 months in the 1949-1982 sample. However, the growth rates are low relative to the pre-1982 expansions, as GDP grew an average of $5.4 \%$ and $2.7 \%$ per annum in the 1949-1982 and 1983-2012 subsamples, respectively. As noted above, a rapid recovery phase had previously been a business cycle stylized fact. But, as can be seen in Table 2, rapid recoveries have been distinctively absent following the three recessions since 1984Q1.

(ii) Weakened procyclicality of labor productivity:

The cyclicality of productivity is important to our understanding of the impulses and propagation mechanisms of business cycles. Countercyclical productivity suggests that labor market variations are due to shifts in labor supply, while procyclical productivity is consistent with shifts in the production function as the driver of economic fluctuations. Procylical productivity is a key driver of the real business cycle literature, (Basu and Fernald, 2001). But during the last two recessions (as dated by the NBER), labor productivity actually rose. Table 3 documents correlations between the log first differences of output, hours and labor productivity as measured by output her hour over different sample periods. On net, over the 1984-2012 period labor productivity growth was less procyclical than it had been in previous business cycles. The difference between the productivity-output correlation in the 1960-1983 and 1984-2012 subsamples is statistically significant at the 10 percent level. The extent to which productivity has become less procyclical is however sensitive to which productivity measure is used, and also to which detrending method is employed. ${ }^{5}$

(iii) Jobless recovery:

The recoveries from the last three recessions have all been marked by slowly improving labor markets, and are often referred to as jobless recoveries. Table 4 reports the characteristics of GDP growth, employment growth and unemployment during the first eight quarters of expansions.

\footnotetext{
${ }^{5}$ Canova (1998) found that within a wide range of business cycle frequencies, the real wage was highly correlated with GDP over the 1955-1986 sample period, but that the correlation was lower for other measures of productivity. We have used first differencing for detrending - using some other detrending methods, the correlation of detrended productivity and output declines more sharply in the post-1984 sample (Gali and Gambetti, 2009; Gali and van Rens, 2010). At the same time, using the utilization-adjusted productivity measure of Basu, Fernald, and Kimball (2006) shows less evidence of a decline in the output-productivity correlation.
} 
Table 3: Business Cycle Correlations (Nonfarm Business Sector)

\begin{tabular}{cccc}
\hline \hline & Output+Hours & Output+Prod & Hours+Prod \\
\hline 60Q1-83Q4 & 0.74 & 0.78 & 0.16 \\
84Q1-06Q4 & 0.53 & 0.55 & -0.42 \\
07Q1-12Q4 & 0.80 & 0.41 & -0.23 \\
84Q1-12Q4 & 0.66 & 0.50 & -0.32 \\
60Q1-12Q4 & 0.70 & 0.69 & -0.03 \\
\hline p-val & 0.62 & 0.08 & 0.00 \\
\hline \hline
\end{tabular}

Notes: Correlation of log first differences of quarterly data. Total output and hours have been scaled by the civilian noninstitutional population. Productivity is defined as the ratio of total output to total hours. The last row of the table, labeled p-val, reports the p-value from a two-sided test of the hypothesis that the correlations in the 60Q1-83Q4 and 84Q1-12Q4 subsamples are equal (using the Bartlett formula with 8 lags). All variables refer to the non-farm business sector.

Table 4: Selected Characteristics of Early Stage Expansions

\begin{tabular}{|c|c|c|c|c|c|}
\hline & Statistic & Largest Value & Smallest Value & Mean & St. Dev. \\
\hline & \multicolumn{5}{|c|}{$1949-1982$} \\
\hline \multirow[t]{2}{*}{ GDP } & Total Change & 19.5 & 4.2 & 11.6 & 4.3 \\
\hline & Annual \% Change & 9.7 & 4.2 & 6.0 & 1.7 \\
\hline Employment & Annual \% Change & 5.9 & 2.0 & 3.5 & 1.2 \\
\hline \multirow[t]{2}{*}{ Unemployment } & Annual Decline & -2.2 & -0.3 & -1.0 & 0.7 \\
\hline & \multicolumn{5}{|c|}{ 1983-2012 } \\
\hline \multirow[t]{2}{*}{ GDP } & Total Change & 6.0 & 5.3 & 5.7 & 0.4 \\
\hline & Annual \% Change & 3.0 & 2.7 & 2.9 & 0.2 \\
\hline Employment & Annual \% Change & 0.6 & -0.3 & 0.2 & 0.5 \\
\hline Unemployment & Annual Decline & -0.2 & 0.2 & 0.0 & 0.2 \\
\hline
\end{tabular}

Notes: This Table shows the properties of the first eight quarters of postwar expansions as dated by the NBER. All entries are in percentage points.

An increase in GDP growth of one percentage point is associated with a $3.5 / 6.0=$ 0.58 percentage point increase in employment during the early stages of 1949-1982 expansions, but this ratio decreased to $0.2 / 2.9=0.07$ when computed over the expansions between 1983 and 2012. Combined with Table 3, it appears that the recoveries from these last three recessions were characterized by productivity growth more than increases in employment or hours worked.

(iv) Pronounced leverage cycle:

Leverage increased before both the 2001 recession and especially before the Great Recession. Table 5 tabulates the HP-trend and cycle ratio of assets to liabilities of 
households and firms. There is an apparent downward trend in both ratios. In each of the last two recessions, the cyclical component of household leverage swung from being positive before the peak to being negative during and after the recession. In the Great Recession, the leverage cycle is more pronounced for households than for firms.

Table 5: Asset/Liability Ratio

\begin{tabular}{c|rrrr|rrrr}
\hline \hline & \multicolumn{4}{|c|}{ Households } & \multicolumn{4}{c}{ Firms } \\
\hline Recession & $\begin{array}{r}\text { Trend } \\
\text { during }\end{array}$ & $\begin{array}{r}\text { Cycle } \\
\text { during }\end{array}$ & $\begin{array}{r}4 \text { qrts } \\
\text { before } \\
\text { peak }\end{array}$ & $\begin{array}{r}\text { 8 qrts } \\
\text { after } \\
\text { trough }\end{array}$ & $\begin{array}{r}\text { Trend } \\
\text { during }\end{array}$ & $\begin{array}{r}\text { Cycle } \\
\text { during }\end{array}$ & $\begin{array}{r}4 \text { qrts } \\
\text { before } \\
\text { peak }\end{array}$ & $\begin{array}{r}\text { 8 qrts } \\
\text { after } \\
\text { trough }\end{array}$ \\
\hline 69Q4-70Q4 & 8.236 & -0.049 & 0.050 & 0.166 & 2.807 & -0.021 & -0.032 & 0.024 \\
73Q4-75Q1 & 7.904 & -0.196 & 0.067 & 0.122 & 2.719 & 0.069 & 0.009 & -0.059 \\
80Q1-82Q4 & 7.588 & 0.083 & -0.173 & 0.133 & 2.507 & 0.018 & -0.008 & 0.016 \\
90Q3-91Q1 & 6.713 & 0.008 & -0.041 & 0.018 & 2.018 & 0.044 & 0.022 & -0.020 \\
01Q1-01Q4 & 6.512 & -0.066 & 0.222 & -0.294 & 2.046 & -0.033 & -0.022 & -0.045 \\
07Q4-09Q2 & 5.333 & -0.327 & 0.213 & -0.032 & 2.205 & -0.027 & 0.102 & -0.060 \\
\hline before 1990 & 7.909 & -0.054 & -0.019 & 0.140 & 2.678 & 0.022 & -0.010 & -0.006 \\
after 1990 & 6.186 & -0.128 & 0.132 & -0.103 & 2.089 & -0.006 & 0.034 & -0.042 \\
\hline
\end{tabular}

Notes: This table shows the household and firm ratios of assets to liabilities from the Federal Reserve flow of funds accounts. For each of the last 6 recessions, the table shows the average of the HP filter trend during the recession, and the average of the HP filter cycle during the recession, over the 4 quarters before the peak, and over the 8 quarters after the trough. The HP filter uses the default smoothing parameter of 1600. Averages for all recessions before 1990 and after 1990 are also shown.

(v) Tight availability of credit giving headwinds to the recovery:

Table 6 reports the average of the net percentage of domestic respondents reporting increased willingness to make consumer installment loans from the Federal Reserve's Senior Loan Officer Opinion Survey in the quarters following business cycle troughs, both for recessions from 1966 to 1985 and for the subsequent three recessions. In the earlier recessions, credit conditions were dramatically eased at the start of the recovery. But, on average over the last three recessions, there was no material easing of consumer credit conditions until one year into the recovery, and even then it was very modest.

The five facts listed above concern features of the three recent economic downtowns. What distinguishes these three recessions is that they were not due to supply and demand shocks of the textbook type. The recession of 1990-1991 was caused by the savings-and-loan crisis. Both the 2001 recession and the Great Recession were preceded by asset price bubbles, 
Table 6: Net Percentage of Respondents Loosening Consumer Credit Standards

\begin{tabular}{ccc}
\hline \hline Quarters after Trough & Average: Recessions pre 1985 & Average: Recessions Post 1985 \\
\hline 0 & 59 & -9 \\
1 & 53 & 1 \\
2 & 50 & -1 \\
3 & 33 & 9 \\
4 & 33 & 10 \\
5 & 37 & 15 \\
6 & 24 & 15 \\
7 & 21 & 17 \\
8 & 25 & 19 \\
\hline \hline
\end{tabular}

Notes: This Table shows the net percentage of domestic respondents reporting increased willingness to make consumer installment loans from the Federal Reserve's Senior Loan Officer Opinion Survey. Percentages are shown for $h$ quarters after the business cycle trough (dated by the NBER) for $h=0, \ldots 8$, are averaged over business cycles.

though the national housing bubble that preceded the Great Recession was far more potent than the internet bubble in the late 1990s, as housing represents a larger fraction of household wealth than stocks. Moreover, the house price collapse affected not only homeowners who faced wealth losses, but also the considerable number whose employment is directly or indirectly related to the construction sector.

\section{Comovements and Common Factors}

Economic analysis of business cycles is often guided by the impulse-propagation framework introduced by Frisch (1933) and Slutsky (1937) under which fluctuations arise as small white noise shocks (impulses) that propagate through the economic system over time. The coherence and phase characteristics of many economic time series appeared to be similar across countries. Lucas (1977) concluded that business cycles are all alike. Not only are bivariate correlations between industrialized countries strong as shown in Table 7, but business cycles of developing economies also have characteristics similar to those of developed countries. Kose, Otrok, and Whiteman (2003) allow regional and country-specific cycles to coexist with the world business cycle and find that the world factor accounts for a significant fraction of output growth fluctuations in many countries.

An alternative to the small-shocks view is that business cycles are dominated by infrequent large events, such as the Great Depression of the 1930s or the oil price shocks of the 
Table 7: International Facts

Correlation with US GDP Growth

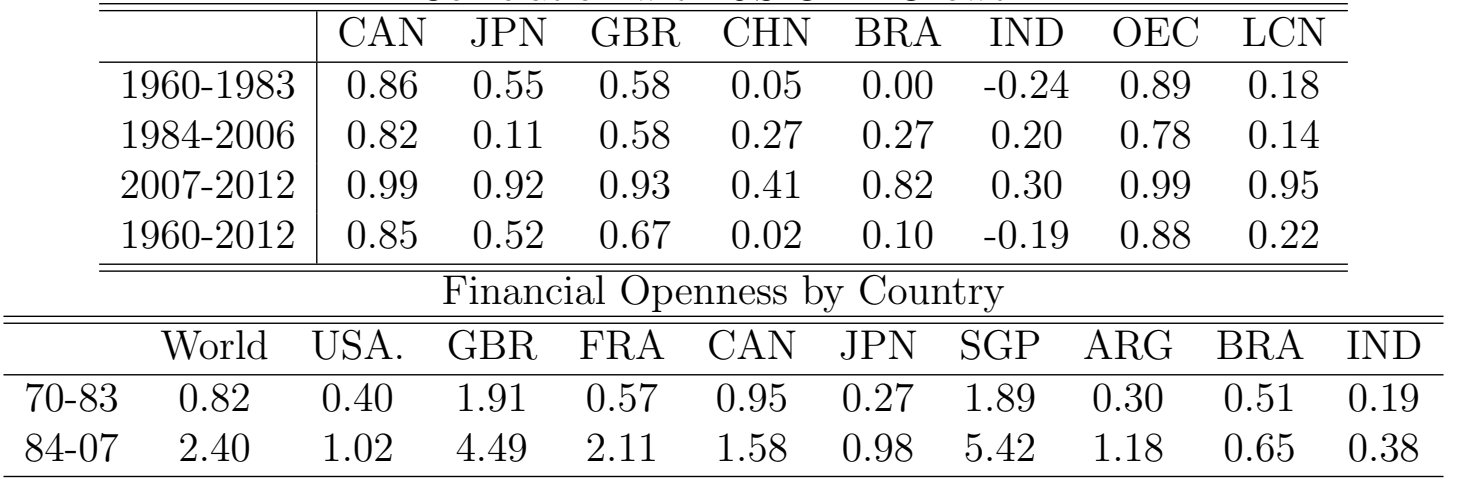

Notes: The upper panel gives correlations of quarterly GDP growth between the US and other countries (Canada, Japan, UK, China, Brazil, India, OECD and Latin America and Carribean). The bottom panel gives the sum of external financial assets and liabilities divided by GDP, from the database of Lane and Milesi-Ferretti (2007).

1970s. Blanchard and Watson (1986) find evidence for both large and small shocks and suggest that business cycle fluctuations are not all alike. New theories of economic fluctuations have also emerged. Barro (2006) and Gourio (2012) suggest that the anticipation of the possibility of rare large economic shocks can generate declines in real activity, while Bansal and Yaron (2004); Bansal, Kiku, and Yaron (2010) argue for the importance of long run risks. Blanchard (1997) and Comin and Gertler (2006) stressed the importance of medium run fluctuations as the economy goes from the business cycle stage to growth. It is fair to say that economists have not settled on a satisfactory explanation for why fluctuations arise. Perhaps they never will, if different causes of economic fluctuations have many observationally equivalent characteristics.

Comovements in a wide range of series play a fundamental role in business cycle analyses in the tradition of Burns and Mitchell (1946) (see for example Diebold and Rudebusch (1996)). A methodological development since the work of Zarnowitz (1985) is that econometricians have settled on the idea of representing these comovements using factor analysis. The factor representation of a series $x_{i t}$, given by

$$
x_{i t}=\lambda_{i}^{\prime} F_{t}+e_{i t}
$$

where $F_{t}=\left(F_{1 t}, \ldots F_{r t}\right)^{\prime}$ is a vector of $r$ common factors, $\lambda_{i}$ is the vector of factor loadings, and $e_{i t}$ is the idiosyncratic error. Factor analysis decomposes the variations into those that are pervasive and those that are idiosyncratic. Shocks with pervasive effects are the source 
of comovements. ${ }^{6}$

To present a factor view of business cycles, we estimate the factors from a monthly panel of 132 series $^{7}$. The factors are estimated by the method of static principal components (PCA) over the full sample 1960-2011. ${ }^{8}$ The $I C_{2}$ criterion Bai and $\mathrm{Ng}$ (2002) finds seven factors accounting for almost $42 \%$ of the variation in the data. Table 8 reports the standard deviation of the factor estimates.

Table 8: Standard Deviations of Factor Estimates

\begin{tabular}{c|ccccccc|c}
\hline Factor & 1 & 2 & 3 & 4 & 5 & 6 & 7 & \\
\hline $\begin{array}{c}\text { Most corr. } \\
\text { Series }\end{array}$ & $\begin{array}{c}\text { IP:mfg. } \\
\text { goods }\end{array}$ & $\begin{array}{c}\text { Baa } \\
\text { spread }\end{array}$ & $\begin{array}{c}\text { CPI-U } \\
\text { comm }\end{array}$ & $\begin{array}{c}1 \text { yr } \\
\text { Tbond }\end{array}$ & $\begin{array}{c}6 \mathrm{~m} \\
\text { spread }\end{array}$ & $\begin{array}{c}\text { IP: } \\
\text { cons.gd }\end{array}$ & $\begin{array}{c}\text { SP } \\
500\end{array}$ & $\begin{array}{c}\text { common } \\
\text { comp. }\end{array}$ \\
\hline 1960:3-1983:12 & 0.47 & 0.33 & 0.19 & 0.26 & 0.24 & 0.18 & 0.16 & 0.68 \\
1984:1-2006:12 & 0.26 & 0.17 & 0.24 & 0.17 & 0.16 & 0.16 & 0.16 & 0.47 \\
2007:1-2011:12 & 0.47 & 0.26 & 0.48 & 0.22 & 0.17 & 0.21 & 0.23 & 0.75 \\
1960:3-2011:12 & 0.40 & 0.27 & 0.25 & 0.22 & 0.20 & 0.17 & 0.17 & 0.62 \\
non-recession & 0.28 & 0.23 & 0.22 & 0.18 & 0.18 & 0.16 & 0.16 & 0.50 \\
recession & 0.48 & 0.42 & 0.38 & 0.38 & 0.26 & 0.23 & 0.22 & 0.86 \\
\hline
\end{tabular}

To facilitate interpretation of the estimated factors, we identify the series that load most heavily on each of the factors. These are industrial production of manufacturing goods, the risky spread between Baa bonds and the Fed funds rate, the commodity component of the CPI, one year bond rate, the 6 month-Fed Funds spread, industrial production of consumer goods, and the SP500 index, respectively. Observe that five of the seven factors are related to financial markets. The factors are noticeably more variable during recession years than the non-recession years. Factor 1 (relating to real activity) has a standard deviation of 0.48 during recession years but only 0.28 during non-recession years. The last factor is highly correlated with stock returns. Higher volatility in returns during recessions appears to be a business cycle regularity, (Andersen, Bollerslev, Christoffersen, and Diebold, 2012). The last column of Table 8 measures the importance of the factors jointly (i.e. the common component of the data). It is cross-section average of the standard deviation of the common component $\hat{C}_{i t}=\hat{\lambda}_{i}^{\prime} \hat{F}_{t}$ over different subsamples. Since the factors are computed using

\footnotetext{
${ }^{6}$ Equation (1) is a static factor model in which the dynamics of the factors are not explicitly modeled. See Stock and Watson (2002a) Bai and Ng (2008) for a review of the literature. Dynamic factor models are also widely used in macroeconomic analysis, see Forni, Hallin, Lippi, and Reichlin (2000).

${ }^{7}$ Stock and Watson (2005), Ludvigson and $\mathrm{Ng}$ (2009) used the same 132 series but over a shorter sample.

${ }^{8}$ The normalization $\Lambda^{\prime} \Lambda / N=I_{r}$ is imposed. As a robustness check, the factors are also estimated using two other ways. Method (ii) assumes that $\alpha_{i}(L) y_{i t}=\lambda_{i}^{\prime} F_{t}+e_{i t}$. Using $\hat{\alpha}_{i}(L)$ from preliminary estimation of an AR(4) model, $F_{t}$ is estimated by PCA. Method (iii) iteratively estimates $F_{t}$ depends on $\alpha_{i}(L)$, as in Stock and Watson (2005).
} 
standardized data, this gives an idea of the relative importance of the common variations. The average variation of the common component is counter-cyclical, as it is much higher during recessions. ${ }^{9}$

Table 9: Stochastic Volatility $(\times 10))$

\begin{tabular}{c|ccccccc}
\hline$j$ & 1 & 2 & 3 & 4 & 5 & 6 & 7 \\
\hline $\begin{array}{c}\text { Most corr. } \\
\text { Series }\end{array}$ & $\begin{array}{c}\text { IP:mfg. } \\
\text { goods }\end{array}$ & $\begin{array}{c}\text { Baa } \\
\text { spread }\end{array}$ & $\begin{array}{c}\text { CPI-U } \\
\text { comm }\end{array}$ & $\begin{array}{c}1 \text { yr } \\
\text { Tbond }\end{array}$ & $\begin{array}{c}6 \mathrm{~m} \\
\text { spread }\end{array}$ & $\begin{array}{c}\text { IP: } \\
\text { cons.gd }\end{array}$ & $\begin{array}{c}\text { SP } \\
500\end{array}$ \\
\hline $1960: 3-1983: 12$ & 0.70 & 0.65 & 0.74 & 1.11 & 0.47 & 0.12 & 0.22 \\
$1984: 1-2006: 12$ & 0.22 & 0.16 & 0.85 & 0.31 & 0.15 & 0.15 & 0.33 \\
$2007: 1-2011: 12$ & 0.53 & 0.24 & 1.58 & 0.45 & 0.19 & 0.15 & 0.51 \\
1960:3-2011:12 & 0.70 & 0.53 & 1.07 & 0.82 & 0.40 & 0.16 & 0.33 \\
non-recession & 0.56 & 0.44 & 0.84 & 0.64 & 0.35 & 0.14 & 0.28 \\
recession & 0.94 & 0.66 & 1.52 & 1.16 & 0.52 & 0.15 & 0.37 \\
\hline
\end{tabular}

Notes: This table is based on fitting the model $\hat{F}_{t j}=\sum_{k=1}^{4} \phi_{k} \hat{F}_{t-k, j}+\sigma_{t, j}^{F} \epsilon_{t, j}^{F}$ to each factor, and reports the averages of the smoothed estimates of the stochastic volatility $\sigma_{t, j}^{F}$ over different periods.

A notable feature in Table 8 is the reduction in volatility of the seven factor estimates and of the relative importance of the common component in the 1984Q1 to 2006Q4 subsample. This bears out the Great Moderation phenomenon from the perspective of common factors rather than the selected series. In addition to unconditional volatility, it is also useful to consider the time varying volatility in the factor estimates. Let $\sigma_{j t}^{F}$ denote the conditional standard deviation of factor $j .{ }^{10}$ Properties of the monte-carlo markov chain estimates $\hat{\sigma}_{t, j}^{F}$ (multiplied by ten) are reported in Table 9 . With the exception of factor 3 which loads heavily on commodity prices, the conditional volatilities of the factors are also significantly lower during the Great Moderation. The shocks to $\hat{F}_{3}$ were historically quite volatile both before 1983 and even during the Great Moderation, which can perhaps be attributed to the oil and commodity price shocks.

Explanations for why volatility declined around 1984 include improved inventory control and supply chain management, better fiscal and monetary policy, and simply good luck from being hit by smaller productivity and commodity price shocks. Another explanation is that the manufacturing sector, which has relatively volatile total factor productivity growth-

\footnotetext{
${ }^{9}$ We also compute the standard deviation of $\hat{C}_{i t}$ across $i$ and then take the average over $t$. Heterogeneity is much higher during recessions.

${ }^{10}$ The model specifies that the error term for each factor $j=1,2, \ldots 8$ is $u_{j t}^{F}=\sigma_{j t}^{F} \varepsilon_{j t}^{F}$ where $\ln \left(\sigma_{j t}^{F 2}\right)=$ $\mu+\phi \ln \left(\sigma_{j t}^{F 2}\right)+\kappa \eta_{j t}^{F}$ and $\left(\varepsilon_{j t}^{F}, \eta_{j t}^{F}\right)^{\prime}$ is an iid normal random variable with mean zero and identity variancecovariance matrix.
} 
has declined in importance since the late 1970s. With other more stable sectors rising in relative importance, the volatility of macroeconomic aggregates naturally declined.

The Great Moderation was disrupted around 2007. As seen from Table 8, the volatility of all 7 factors rose going from the Great Moderation to the Great Recession. The volatilities of $\hat{F}_{3}$ and $\hat{F}_{7}$, which load heavily on commodity prices and stock prices, respectively climbed above their pre-Great Moderation levels. Table 9 shows that the conditional volatility of the factor estimates are also higher after 2007. This disruption leads one to reconsider whether the assumption that the Great Moderation would last forever is overly optimistic. And indeed, with the benefit of hindsight, it seems noteworthy that even during the 1984-2006 period, the decline in volatility was mostly at high frequencies. As Davis and Kahn (2008) pointed out, the variance of four-quarter changes in aggregates declined, but less markedly. Also, while the Great Moderation was observed in most countries, the timing and magnitude of the decline in volatility differed substantially across countries (Stock and Watson, 2003a).

The jury is still out on whether the Great Moderation has truly ended, or whether volatility will return to the low level observed before 2007. There are signs that it might, as GDP growth has been stable (though sluggish) since early 2009. But aggregate volatility is a weighted average of sectoral volatility, with weights reflecting the relative importance of the sectors. These weights are quite different in the digital age than fifty or even twenty years ago. Time varying volatility is to be expected in a changing economy.

\section{The Great Recession}

The Great Recession of 2007 to 2009 was not officially announced by the NBER business cycle dating committee until December 2008. It lasted 18 months and was long by post WW-II standards, even though it was still shorter than the contractions before WW-I, which averaged 22 months. ${ }^{11}$ The Great Recession was characterized by a lower mean growth rate, stagnant real wages, and by higher volatility in consumption, investment, output, as well as inflation. This can be seen from the standard deviations of factors $\hat{F}_{1}$ to $\hat{F}_{7}$ reported in Table 8.

There are also indications of a shift in the relation between vacancies (job openings) and unemployment in the aftermath of the Great Recession. Traditionally, recessions are periods of high unemployment with low job openings, yielding a negative relationship between the vacancy rate and the unemployment rate, known as the Beveridge curve (Beveridge, 1944).

\footnotetext{
${ }^{11}$ Aruoba and Diebold (2010) use a dynamic factor model to extract indices of real activity and inflation. Their index of real activity fell to a very low (but not record low level) during the Great Recession, and was low for a very long period.
} 
Movements along a convex Beveridge curve are taken to be cyclical shocks while shifts are typically viewed as structural changes relating to the job matching process. Daly, Hobijn, Sahin, and Valletta (2012) discuss the Beveridge curve at length, finding that the Great Recession shifted it to the right by over 2 percentage points, although they argue that much of this may be the slow adjustment of the unemployment-vacancy relationship in the aftermath of a severe recession rather than a permanent shift in the Beveridge curve.

The Great Recession also involved a sharp drop in labor force participation rates, meaning that the unemployment rate has moved further back towards its pre-crisis level than has the employment-population ratio. Explanations of non-financial origins have been put forward for the slow and jobless recovery from the Great Recession. Some, such as Stock and Watson (2012), argue that this could be due to structural demographic factors, including the leveling out of female labor force participation and the aging of the population. However, Erceg and Levin (2013) provide evidence that cyclical factors account for most of the recent decline in the labor force participation rate. Others argued that the slow recovery owes to increased skills mismatch, though there is little evidence that wages of the workers whose skills were in special demand have been rising. Also, the dispersion across industries in employment growth spiked during the Great Recession, but then fell back quickly (Daly, Hobijn, Sahin, and Valletta, 2012), which does not seem to fit the mismatch story. Estevão and Tsounta (2011) estimate that skills mismatch accounts for about half a percentage point of the increase in unemployment since the onset of the Great Recession. They also find that geographical mismatch between where jobs and job seekers are available accounts for another small part of the rise in unemployment.

Uncertainty has been suggested as a contributing factor to the severity of the Great Recession. Bloom (2009) and Bloom, Floetotto, Jaimovich, Saporta, and Terry (2012) suggest that firms facing adjustment costs in capital and labor are more cautious in making hiring and investment decisions when macroeconomic uncertainty is high. In these models, uncertainty affects business conditions at the aggregate, firm, and unit levels. FernándezVillaverde, Guerrón-Quintana, Kuester, and Rubio-Ramírez (2012) and Basu and Bundick (2012) suggest that increased uncertainty about fiscal policy and demand, respectively, can also cause an economic slowdown. The Great Recession was indeed marked by a high level of uncertainty. Jurado, Ludvigson, and Ng (2013) define uncertainty in a series as the time varying volatility of the unforecastable component of the series, while macro or aggregate uncertainty is a weighted average of the uncertainty measures across series. They find that uncertainty was higher in the 2007-2009 recession than at any time since 1960 and that uncertainty shocks have significant and persistent effects on real activity. ${ }^{12}$ An increase in

\footnotetext{
${ }^{12}$ Other commonly-used proxies for uncertainty, such as stock market volatility and cross-sectional variation
} 
uncertainty could of course be more the consequence of a downturn than the cause. Nakamura, Sergeyev, and Steinsson (2012) document a strong negative correlation between first moment shocks and uncertainty shocks. As shown in Bachmann and Moscarini (2011), a negative shock to the first moment of economic activity causes volatility to increase. The increase in uncertainty in the Great Recession could have contributed to the depth of the downturn.

The Great Recession was also exceptionally global in nature. As seen in Table 7, the contemporaneous correlation of GDP growth in the US and most other OECD economies is nearly 1 in the 2007-2012 subsample. Although not reported, correlations have also climbed for emerging market economies, though less dramatically. In contrast, there was little evidence of increased correlations in GDP growth between countries during the Great Moderation $^{13}$, despite the deepening financial linkages (also reported in Table 7) and deepening trade linkages. The increased correlation during the Great Recession could owe in part to standard trade linkages, but contagion from the financial crisis originating in the US housing and mortgage markets is also an essential (and probably much larger) part of the story (Krugman, 2008; Devereux and Yetman, 2010). The global nature of the Great Recession is important because it means that there is no external sector that represents a natural source of demand.

\subsection{The Balance Sheet Effect}

While all of the recessions since 1985 have had financial origins, the Great Recession was by far the biggest of these and the timing of events make the link of the Great Recession to financial markets particularly transparent. Although there had been severe strains in financial markets since August 2007, the collapse of Lehman in September 2008 and the subsequent run on money-market mutual funds led to a panic in financial markets. Many firms experienced a sudden and sharp drop in access to credit, including commercial paper. Within a matter of weeks, this led to sharp declines in economic activity. These events have been discussed extensively elsewhere (e.g. Gorton and Metrick (2012)). Figure 1 shows industrial production and the ISM index, two prominent economic indicators which plunged in the fall of 2008.

The developments in financial markets during the Great Recession are consistent with

in firms' profits, productivity, stock returns (all considered by Bloom (2009)) were also very elevated during the Great Recession, but Jurado, Ludvigson, and Ng (2013) find that these other proxies are generally only weakly correlated with aggregate economic uncertainty.

${ }^{13}$ Imbs (2010) documented the remarkable increase in synchronization of cross-country business cycles around the time of the Great Recession. The result was also found by Doyle and Faust (2005). 
Figure 1: Monthly Economic Indicators around the Great Recession

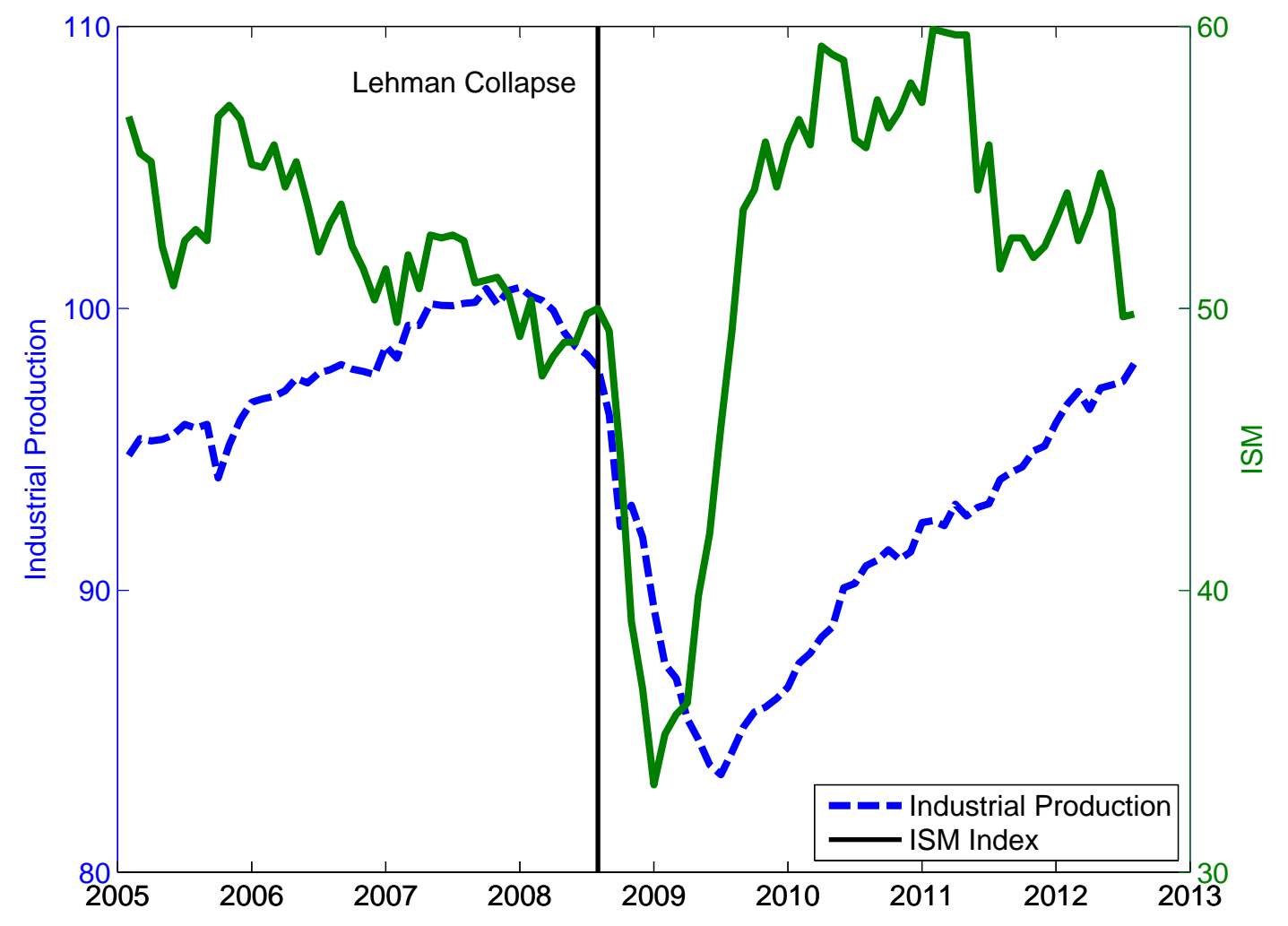

the analysis of Fisher (1933) and Minsky (1986) who argued for the role of credit, leverage and/or asset price bubbles in understanding at least some business cycles fluctuations. The leverage view was neglected in the years leading up to the crisis, but has received a great deal of attention of late ${ }^{14}$. Indeed, according to this view, the Great Recession could even be seen in part as a direct consequence of the Great Moderation, as economic stability leads to overconfidence which in turn sparks a destabilizing rise in leverage (Keen, 1995; Brunnermeier and Sannikov, 2013).

In the Minsky-Fisher view, a sharp increase in leverage leaves the economy vulnerable to small shocks because once asset prices begin to fall, financial institutions, firms and households all attempt to deleverage. But with all agents trying to increase savings simultaneously, the economy loses demand, further lowering asset prices and frustrating the attempt to re-

\footnotetext{
${ }^{14}$ See, for example, Adrian and Shin (2012), Guerrieri and Lorenzoni (2011), Hall (2011), Eggertson and Woodford (2003), and Kroszner, Laeven, and Klingebiel (2007).
} 
pair balance sheets. Financial institutions seek to deleverage, lowering the supply of credit. Households and firms seek to deleverage, lowering the demand for credit. The ensuing downturn is often referred to as a balance sheet recession. Bernanke and Gertler (1989), Bernanke, Gertler, and Gilchrist (1996), Bernanke, Gertler, and Gilchrist (1999), Kiyotaki and Moore (1997), and Brunnermeier, Eisenbach, and Sannikov (2012) consider models with a financial accelerator mechanism, in which financial frictions can give rise to non-linear amplification effects. The recessions can be deep and the recoveries slow. Chodorow-Reich (2013) studies the relationship between the employment level of firms and the health of the banks that these firms have relationships with, and provides evidence that credit market disruptions account for about one third to one half of the decline in employment at small and medium sized firms in the year after the Lehman bankruptcy. Mian, Rao, and Sufi (2011) and Mian and Sufi (2012) attribute the Great Recession to shocks to household balance sheets weakening aggregated demand. Mian and Sufi (2012) show that counties in the US which were most leveraged had the sharpest drop in employment in the non-tradeable sector, whereas job losses in the tradeable sector were much more evenly distributed. This pattern is consistent with the deleveraging and aggregate demand channel being important to explain recent unemployment.

Focusing only on postwar aggregate US time series data necessarily gives a small sample size to evaluate the importance of balance sheet effects in recent downturns. Consequently, it is important to find ways to increase the effective sample size. Many authors have looked at longer time series and also at cross-sectional evidence on the empirical relationship between leverage and the business cycle. This work includes Schularick and Taylor (2012), Reinhart and Rogoff (2009a,b, 2011) and Jorda, Schularick, and Taylor (2011), who have found that credit booms and increases in leverage tend to be followed by economic downturns that are severe and long-lasting, and that the sharper is the pre-crisis increase in leverage, the worse the subsequent recession. ${ }^{15}$ On the other hand, while Bordo and Haubrich (2010) also find that recessions associated with financial crises are exceptionally severe, Bordo and Haubrich (2012) argue that recoveries from such recessions have been rapid in the U.S. The conclusions from such exercises are of course sensitive to the classification of which recessions are caused by financial crises and researchers can reasonably disagree about whether financial factors were causes or symptoms of specific slowdowns. Reinhart and Rogoff (2012) disagree with the classification employed by Bordo and Haubrich (2012), which rather unusually treats the 1981 recession as caused by a financial crisis rather than monetary policy.

\footnotetext{
${ }^{15}$ For example, Mian and Sufi (2010) documented that ZIP codes in the US which had particularly large increases in leverage in the mid 2000s subsequently had the worst downturns. Mian, Rao, and Sufi (2011) and Mian and Sufi (2012) extend these results.
} 


\subsection{Financial Institutions and Monetary Policy}

Financial institutions played a direct role in the deleveraging aspect of the Great Recession, but they also played a less transparent role. Financial intermediation has changed radically over the past three decades, and these changes might have sown the seeds of the financial crisis. In the traditional banking system, money consists of currency issued by the central bank plus liabilities of private banks in the form of demand deposits. Savers supply deposits and banks lend the deposits to borrowers. Banks intermediate by screening and monitoring borrowers while structuring loans with the desired duration and liquidity. As banks rely on short-term liabilities to fund longer-term loans, they are required to hold a fraction of deposits as reserves, which together with deposit insurance guard against bank runs. The Federal Reserve only controls the monetary base (currency plus reserves) through the overnight rate at which banks borrow. For a given amount of deposits, an increase in reserves causes money/credit to shrink. In this traditional framework, the short rate matters for monetary policy to the extent that it affects the yield curve.

But since the 1980s, credit has increasingly been generated outside of the traditional banking system. Whereas in the past banks made loans that they intended to hold on their balance sheet (originate-to-hold), banks instead began to pool the loans into asset-backed securities and then sold them (originate-to-distribute). These asset-backed securities were in turn rehypothecated (i.e. used as collateral for short-term borrowing). Long-term illiquid assets were effectively converted into instruments perceived to have money-like properties, as discussed by Pozsar, Adrian, Ashcraft, and Boesky (2010). But the non-bank institutions holding these instruments were more highly leveraged than traditional banks. They were lightly regulated, not required to hold reserves, and not covered by deposit insurance. For some time, unawareness of the riskiness of the collateral, the counterparty risk, the fragility of these institutions, and of the principal-agent problems inherent in the originate-to-distribute model led to an oversupply of credit (or credit boom). The prolonged leverage cycle documented earlier was fueled by low interest rates and the growth of the shadow banking system. But the high leverage of the shadow banking system left it highly vulnerable to runs, and such a run began in 2007. The Fed had to use liquidity facilities to adjust the quantity rather than the cost of credit in order to counteract the effects of shrinking balance sheets of financial institutions, as discussed by Adrian and Shin (2009).

During the crisis, central banks around the world responded by cutting nominal shortterm interest rates. At the time of writing in mid 2013, these rates in many countries remain at levels very close to zero. ${ }^{16}$ In spite of interest rates near the zero lower bound (ZLB), the

\footnotetext{
${ }^{16}$ As agents always have the option of holding cash, the rates cannot be reduced below zero. There have been some cases of rates falling very slightly below zero, but still for all practical purposes, zero is the lower
} 
output gap remains large and persistent. The US faced extended ZLB periods both in the Great Depression and the Great Recession, and has had other near brushes with it, such as in 2003.

The ZLB impedes the ability of monetary policy to stabilize the economy, and even presents the potential for the economy to enter into a deflationary spiral. ${ }^{17}$ To date, the Great Recession has not been associated with deflation in any country outside Japan. Undershooting their inflation targets is a real concern for central banks as inflationary pressures are nowhere to be found, quite unlike the situation after the recessions of the 1970s and 1980s. In a weak economy, with nominal rates stuck at zero, lower inflation drives real rates up, further weakening demand, and lowering inflation even more. With their respective economies stuck at the ZLB, several central banks including the Fed have launched asset purchase programs, often referred to as quantitative easing, to try to speed up their recoveries. The idea is that by purchasing assets, the central bank will signal its commitment to keeping rates low (Eggertson and Woodford, 2003) and/or lower term/risk premia.

\section{$5 \quad$ Implications for Forecasting}

The financial crisis and the Great Recession call for the need to better monitor credit, asset prices, and more generally to capture the possibly non-linear link between real and financial variables that seem to be different from recessions of the 1970s and 1980s. When recessions are of different origins, three questions become central for economic forecasting and monitoring:- is the predictive power of the key variables stable, are conventional models and methodologies providing timely signals of recessions, and are the necessary data available?

\subsection{The Predictive Power of Interest Rate Spreads}

Asset prices are forward-looking variables that are available at high frequency, and that ought to contain information about investors' beliefs concerning the near-term path of the economy. One might therefore hope that asset prices would be useful for predicting economic activity, and this question has indeed generated a vast literature (see Stock and Watson (2003b) and the references therein). Alas, the track record of forecasting models using asset prices is not good, or at least not consistent. As observed by Hamilton (2011), there are many cases of forecasting methods working well in-sample, or even in pseudo-out-of-sample experiments, but then subsequently giving poor forecasts.

bound on nominal interest rates.

${ }^{17}$ See, for example, Adrian and Shin (2012), Guerrieri and Lorenzoni (2011), Hall (2011), Eggertson and Woodford (2003) and Reifschneider and Williams (2000). 
Many papers attempt to use the term structure of nominal interest rates to forecast growth. If changes in the stance of monetary policy were important drivers of business cycle fluctuations, then we would expect the slope of the yield curve to have predictive power for future growth. For example, if the Fed were to tighten monetary policy, then this would cause short term interest rates to go up, long-term interest rates to go down (lower expected inflation) and so cause the yield curve to flatten or even invert. And it would cause a slowdown in economic activity.

In addition to term spreads, various researchers have considered using spreads on privatesector securities over comparable maturity Treasuries to forecast economic activity. The idea is that widening spreads ought to indicate expectations of default or disruptions to the supply of credit. However, the results are sensitive to the choice of credit spread and sample period. Part of the problem is that conventional indices of credit spreads are all for a particular credit rating, and the meanings of these ratings vary over time. Recently, some papers find that credit spreads formed from comparing individual corporate bonds with comparable maturity Treasuries, and then sorting these into portfolios by maturity and distance-to-default contain substantially more out-of-sample predictive power for future economic activity than conventional corporate bond spreads, (see Gilchrist, Yankov, and Zakrajsek (2008), Gilchrist and Zakrajsek (2012) and Faust, Gilchrist, Wright, and Zakrajsek (2013)).

While there are reasons to believe that term and credit spreads should have some predictive power for economic activity, the question is whether the predictive power is robust. To address this question, we consider a predictive model of the form

$$
y_{t+h}^{h}=\beta_{0}+\Sigma_{j=1}^{p} \beta_{j} y_{t-j}+\gamma z_{t}+\varepsilon_{t}
$$

where $y_{t}$ denotes growth in real GDP or some other aggregate in quarter $t$ (defined as $\left.100 \log \left(G D P_{t} / G D P_{t-1}\right)\right), y_{t+h}^{h}$ denotes $h+1$-period growth ending in quarter $t+h\left(y_{t+h}^{h} \equiv\right.$ $\left.\sum_{j=0}^{h} y_{t+j}\right)$, and $z_{t}$ is some spread. The equation is estimated in rolling 40-quarter windows, and then used for pseudo out-of-sample forecasting. The forecasts are then compared to those from an autoregressive benchmark that omits the spread variable:

$$
y_{t+h}^{h}=\beta_{0}+\Sigma_{j=1}^{p} \beta_{j} y_{t+1-j}+\varepsilon_{t}
$$

Figure 2 shows the rolling 40-quarter moving average of root mean square prediction errors (RMSPEs) from estimating (2) relative to those from estimating equation (3), where the predictor $z_{t}$ is either the ten-year over three-month Treasury spread (top panels) or the excess corporate bond spread of Gilchrist and Zakrajsek (2012) (bottom panels). Results 
Figure 2: Rolling Relative Predictive Accuracy of Term and Credit Spreads
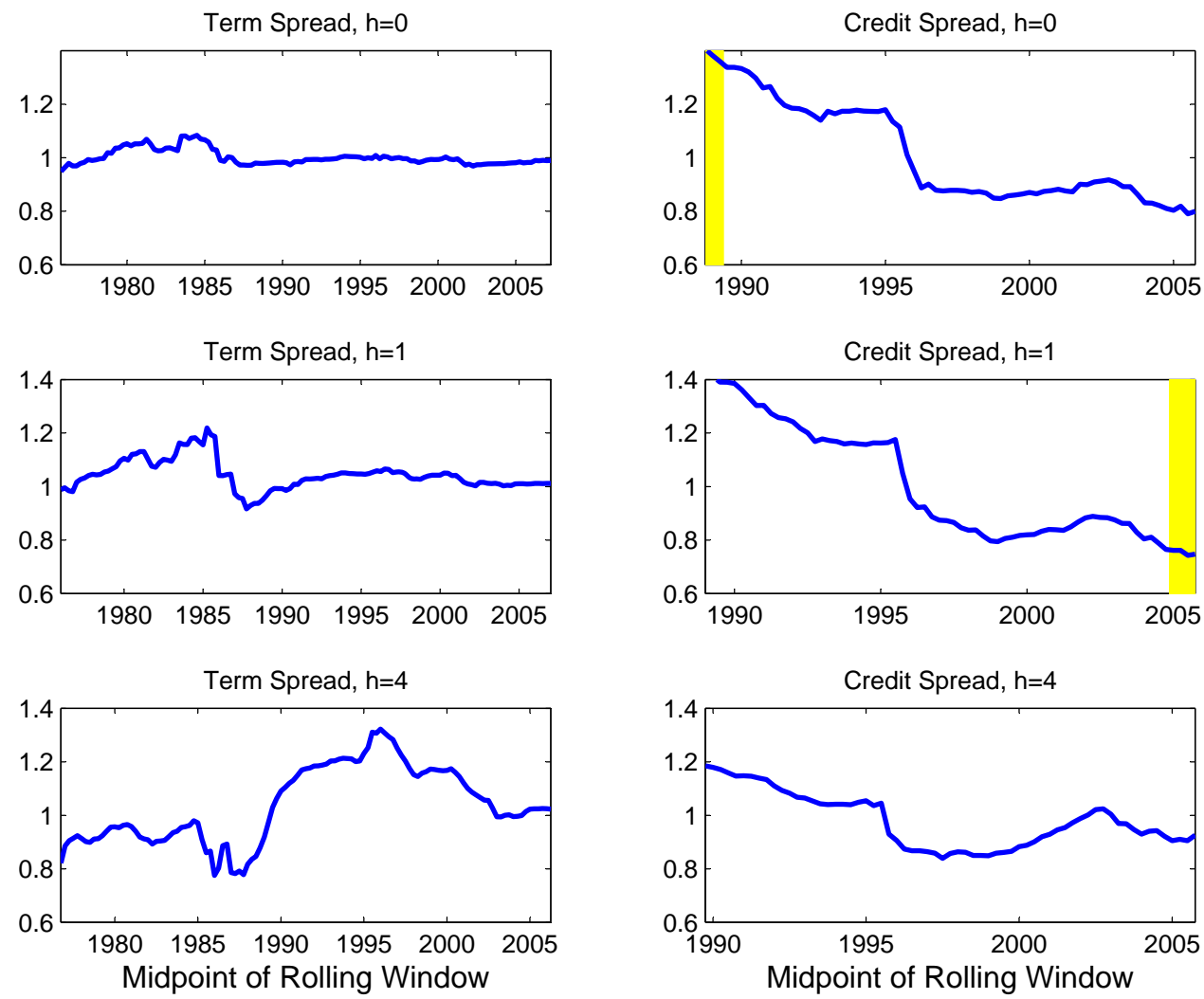

Notes: This shows the rolling 40-quarter moving average of root mean square prediction errors (RMSPEs) from estimating the augmented regression (Equation 2) relative to those from the benchmark equation (Equation 3). Results are plotted against the midpoint of the rolling window and are shown for different horizons $(h)$ and with either term or credit spreads in the augmented regression. The shaded region denotes the midpoints of windows in which the fluctuation test of Giacomini and Rossi (2010) rejects the null hypothesis of equal forecast accuracy.

are shown for horizons of $h=0$ quarters (nowcasting) $h=1$ quarter and $h=4$ quarters. $^{18}$ The rolling relative RMSPEs are plotted against the middle quarter of the 40-quarter period. For windows centered in the early 1980s, the relative RMSPE at the four-quarter-horizon for the term spread is well below 1, indicating that the term spread is indeed adding incremental predictive information. However, later in the sample, inclusion of the term spread substantially weakens forecast accuracy. ${ }^{19}$ The results are quite different for the corporate

\footnotetext{
${ }^{18}$ The Treasury term spread data are from 1960Q1 to 2012Q1. The corporate spread data are from 1973Q1 to 2010Q3, from Gilchrist and Zakrajsek (2012).

${ }^{19}$ The yield curve was inverted in 2006 and early 2007, but the yield curve had steepened once again well before the Great Recession reached its acute phase, and in recent years, the yield curve has been steep, even though growth has been weak.
} 
spreads. For windows centered around 1990, inclusion of corporate spreads gives less accurate forecasts than the autoregressive benchmark. But, later in the sample, inclusion of the credit spread helps a good deal, especially at short horizons. This is consistent with the availability of credit being important factors in explaining recent business cycle fluctuations. The credit spreads considered here widened substantially in late 2007 and the first half of 2008. At the same time, the out-of-sample estimation of (2) using the credit spreads of Gilchrist and Zakrajsek (2012) failed to predict the magnitude of the downturn in the fall of 2008. The results suggest that the performance of the term and credit spreads as predictors of economic activity is somewhat episodic. ${ }^{20}$

One can ask if the difference between the squared forecast error using equation (3) and equation (2) is related to other variables in the information set at the time the forecast is made denoted $w_{t}$, as suggested by Giacomini and White (2006). ${ }^{21}$ We let $w_{t}$ be the GDP share of the financial sector and/or household or firm asset-liabilities ratios. The results are shown in Table 10 for different horizons and variables in $w_{t}$. The larger is the size of the financial sector, or the more leveraged are households and firms, the more the inclusion of credit spreads helps with forecasting performance. The relationship is statistically significant in nearly every case.

There are a number of different stories to explain this relationship. One is that credit spreads are more useful predictors of economic activity in a more highly leveraged economy. Another possibility is that leverage has trended up, and at the same time, developments in financial markets mean that credit spreads provide more information than they had previously. But our results are consistent with the idea that business cycle fluctuations have different origins. The recessions of the early 1980s were caused by the Fed tightening monetary policy so as to lower inflation, with the effect of generating both an inverted yield curve and two recessions. The origins of the Great Recession were instead in excess leverage and a housing/credit bubble.

This is not a happy state of affairs from a standard forecasting perspective. If the relevant predictors are constantly changing over time, then there is little hope for anticipating business cycle fluctuations ahead of time using simple models with few predictors as in (3). Recent work that exploits the data rich environment to form either averages of many predictors or averages of many models holds some promise in providing better forecasts, but even these

\footnotetext{
${ }^{20}$ A similar finding was reported in (Giacomini and Rossi, 2010; Rossi and Sekhposyan, 2010). Ng (2013) also finds that term and credit spreads have independent explanatory power in predicting recessions, but their relative importance varies over time and no single spread performs systematically well.

${ }^{21}$ If one forecast is better than another only conditional on some other observed variable, then both forecasting models must be in some way misspecified. But writing out the correctly specified or encompassing model is not a trivial exercise.
} 
Table 10: Test of Conditional Predictive Ability Using Credit Spreads

\begin{tabular}{|c|c|c|c|c|c|}
\hline Horizon & Intercept & $\begin{array}{c}\text { Fin. Share } \\
\text { of GDP }\end{array}$ & $\begin{array}{l}\text { HH Assets/ } \\
\text { Liabilities }\end{array}$ & $\begin{array}{c}\text { Firm Assets/ } \\
\text { Liabilities }\end{array}$ & p-value \\
\hline \multirow[t]{8}{*}{$\overline{c h}=0$} & -21.60 & 2.96 & & & 0.000 \\
\hline & $(5.07)$ & $(0.70)$ & & & \\
\hline & 20.25 & & -3.26 & & 0.000 \\
\hline & $(5.78)$ & & $(0.90)$ & & \\
\hline & 19.46 & & & -9.58 & 0.019 \\
\hline & $(8.61)$ & & & $(4.07)$ & \\
\hline & 19.58 & 2.12 & -1.72 & -11.56 & 0.000 \\
\hline & (13.08) & $(0.64)$ & $(0.82)$ & $(3.65)$ & \\
\hline \multirow{8}{*}{$h=1$} & -22.71 & 3.20 & & & 0.000 \\
\hline & $(5.35)$ & $(0.77)$ & & & \\
\hline & 29.95 & & -4.68 & & 0.000 \\
\hline & $(8.07)$ & & $(1.22)$ & & \\
\hline & 23.61 & & & -11.28 & 0.003 \\
\hline & $(7.97)$ & & & $(3.73)$ & \\
\hline & 49.68 & 1.11 & -4.14 & -14.84 & 0.000 \\
\hline & $(18.40)$ & $(0.77)$ & $(1.46)$ & $(3.59)$ & \\
\hline \multirow[t]{8}{*}{$h=4$} & -4.93 & 0.73 & & & 0.014 \\
\hline & (1.91) & $(0.30)$ & & & \\
\hline & 9.68 & & -1.47 & & 0.017 \\
\hline & (4.12) & & $(0.61)$ & & \\
\hline & 5.34 & & & 3.55 & 0.155 \\
\hline & $(3.55)$ & & & $(1.72)$ & \\
\hline & 19.1900 & -0.10 & -1.66 & -3.63 & 0.001 \\
\hline & $(9.82)$ & $(0.48)$ & $(0.92)$ & $(1.51)$ & \\
\hline
\end{tabular}

Notes: Regression of $e_{1, t}^{2}-e_{2, t}^{2}$ onto a constant and the financial share of GDP and/or the firm or household asset-liabilities ratio, where $e_{1, t}$ and $e_{2, t}$ are the rolling out-of-sample forecast errors from the benchmark regression and the augmented regression using credit spreads, respectively. Heteroksedasticity robust standard errors are used. This test of conditional predictive ability follows Giacomini and White (2006).

methods are not immune to the possibility that the averaging weights may change over time. In the words of Nils Bohr, "Prediction is very difficult, especially if it is about the future."

\subsection{Calling Turning Points in Real Time}

Related to the idea of forecasting business cycles is the idea of identifying business cycle turning points as accurately and quickly as possible. Harding and Pagan (2006), Chau- 
vet and Hamilton (2006) and Chauvet and Piger (2008) propose automatic methods for identifying business cycle peaks and troughs in real time, which is related to the idea of nowcasting. It is an important endeavor because the NBER announcements involve an element of subjective judgment which econometricians might prefer to avoid, and because the NBER announcements come out with a considerable lag. The turning point dates proposed by these methods are generally quite close to NBER dates. The algorithms call the peaks and troughs at roughly the same time as the NBER announcements (Hamilton, 2011). Hamilton (2011) discusses reasons why it is hard to reduce the lag time. One reason is that real-time data are subject to large revisions. Another is that business cycle features tend to change over time.

To investigate how these methodologies fare in real time, we estimate a probit model for the NBER business cycle dummy for each quarter $t$ starting in 1980Q1 using real time predictors taken from the dataset of the Federal Reserve Bank of Philadelphia or from the Survey of Professional Forecasters (SPF). For the business cycle dummy, peaks and troughs were recorded only after they had been announced. The models that we considered used the following predictors:

(i) The real-time growth rates of industrial production and employment over the previous quarter, as observed in the middle of quarter $t$.

(ii) The probability that real GDP growth is negative in the current quarter, as reported in the SPF survey.

(iii) The real-time growth rate of industrial production in the current quarter, obtained from the SPF. Note that the survey forecast for industrial production growth in the current quarter is not the same as the survey probability in (ii).

(iv) The ten-year over three-month Treasury spread.

(v) The excess corporate bond spread of Gilchrist and Zakrajsek (2012). 
Table 11: Calling Turning Points in Real-Time

\begin{tabular}{|c|c|c|c|c|c|}
\hline \multicolumn{6}{|c|}{ Quarters of Business Cycle Peaks } \\
\hline Determined by NBER & 1980Q1 & 1981Q3 & 1990Q3 & $2001 \mathrm{Q} 1$ & $2007 \mathrm{Q} 4$ \\
\hline Date NBER Made Call & 1980:06 & 1982:01 & 1991:04 & 2001:11 & 2008:12 \\
\hline IP and employment growth in $t-1$ & $\mathrm{NC}$ & 1982Q1 & 1990Q4 & $\mathrm{NC}$ & 2008Q4 \\
\hline Date Call Made & $\mathrm{NC}$ & 1982:05 & 1992:08 & $\mathrm{NC}$ & 2009:05 \\
\hline SPF Recession Probability & 1979Q3 & 1981Q3 & 1990Q4 & $\mathrm{NC}$ & 2008Q4 \\
\hline Date Call Made & 1980:02 & 1981:11 & 1991:02 & $\mathrm{NC}$ & 2009:02 \\
\hline SPF nowcast of IP growth & 1979Q4 & 1981Q4 & 1990Q4 & 2001Q1 & 2008Q2 \\
\hline Date Call Made & 1980:08 & 1982:02 & 1991:02 & 2001:11 & 2008:11 \\
\hline Term Spread & 1979Q2 & 1981Q1 & $\mathrm{NC}$ & $\mathrm{NC}$ & $\mathrm{NC}$ \\
\hline Date Call Made & 1980:02 & 1981:05 & $\mathrm{NC}$ & $\mathrm{NC}$ & $\mathrm{NC}$ \\
\hline Credit Spread & 1981Q3 & $\mathrm{NC}$ & $\mathrm{NC}$ & $2000 Q 4$ & $2008 Q 4$ \\
\hline Date Call Made & 1982:08 & $\mathrm{NC}$ & $\mathrm{NC}$ & 2002:02 & 2009:02 \\
\hline \multicolumn{6}{|c|}{ Quarters of Business Cycle Troughs } \\
\hline Determined by NBER & 1980Q3 & $1982 \mathrm{Q} 4$ & 1991Q4 & $2001 Q 4$ & 2009Q2 \\
\hline Date NBER Made Call & 1981:07 & 1983:07 & 1992:12 & 2003:07 & 2010:09 \\
\hline IP and employment growth in $t-1$ & $\mathrm{NC}$ & 1983Q1 & 1992Q2 & $\mathrm{NC}$ & 2009Q4 \\
\hline Date Call Made & $\mathrm{NC}$ & 1983:08 & 1993:02 & $\mathrm{NC}$ & 2010:05 \\
\hline SPF Recession Probability & 1980Q3 & 1982Q4 & 1991Q2 & $\mathrm{NC}$ & 2009Q2 \\
\hline Date Call Made & 1981:02 & 1983:05 & 1991:11 & $\mathrm{NC}$ & 2009:11 \\
\hline SPF nowcast of IP growth & 1980Q3 & 1982Q4 & 1991Q1 & $2001 \mathrm{Q} 4$ & 2009Q2 \\
\hline Date Call Made & 1981:02 & 1983:05 & 1991:08 & 2002:05 & 2009:11 \\
\hline Term Spread & 1980Q2 & 1981Q4 & $\mathrm{NC}$ & $\mathrm{NC}$ & $\mathrm{NC}$ \\
\hline Date Call Made & 1980:11 & 1982:05 & $\mathrm{NC}$ & $\mathrm{NC}$ & $\mathrm{NC}$ \\
\hline Credit Spread & 1983Q2 & $\mathrm{NC}$ & $\mathrm{NC}$ & $2001 \mathrm{Q} 4$ & 2009Q3 \\
\hline Date Call Made & 1983:11 & $\mathrm{NC}$ & $\mathrm{NC}$ & 2003:08 & 2010:02 \\
\hline
\end{tabular}

Notes: This table shows the dates that recessions began and ended as determined by the NBER and the five automatic methods that we consider. These methods are based on real-time probit regressions of NBER recession dummies onto variables as follows: industrial production and employment growth in the previous quarter (quarter $t-1$ ); SPF probability of negative growth in the current quarter; the SPF forecast of industrial production growth in the current quarter; term spreads in the current quarter; credit spreads in the current quarter. The regression is run using data available at the time of the release of each round of the SPF. A peak is called whenever there are two consecutive quarters where the fitted probability exceeds 65 percent, and the date of the peak is the first quarter that the probability rose above 50 percent. A trough is called similarly. $\mathrm{NC}$ means that the method in question did not call a peak or trough corresponding to this NBER recession. For each method, the row labeled "date call made" indicates the date that the turning point was called. 
Each of these methods gives us the fitted probability of a recession in quarter $t$. Following Hamilton (2011), a peak occurs if the fitted probability exceeds 65 percent, and we date the peak as being the first quarter that this fitted probability exceeds 50 percent. Likewise a trough is called if the fitted probability falls below 35 percent, and we date the trough as being the last quarter that the fitted probability exceeds 50 percent.

Table 11 reports the peak and trough dates called by this algorithm, along with the dates in which the algorithm called the turning points. The NBER turning points and announcement dates are also shown for reference. Method (i) generally agrees with the NBER dates and calls turning points at around the same time. Methods (ii) and (iii) however call the turning points a bit faster. In fact, method (ii) calls every turning point before the NBER announcement with the sole exception of the 2007Q4 trough. However, this algorithm completely missed the 2001 recession, as no trough was ever called. Method (iii) calls all but two turning points no later than the NBER announcement, and does not miss the 2001 recession. Among the financial variables, the term spread called both recessions associated with the Volcker disinflation very quickly, but entirely missed all subsequent recessions - the yield curve inverted around subsequent recessions, but only marginally. In contrast, the credit spread did a reasonably good job of calling the last two recessions, but missed the second Volcker recession and the 1990-1991 recession. All this is consistent with the idea that term and credit spreads are useful, but somewhat episodic, indicators.

It is interesting that the probit model using the SPF probabilities of negative growth in the current quarter or the current-quarter industrial production growth forecast (models (ii) and (iii)) seems to do the best job of calling turning points in real time. It is consistent with the evidence that subjective survey forecasts are very good for measuring the current state

of the economy (Faust and Wright, 2009). At the same time, it is important to underscore that these survey probabilities are purely judgmental. We have no model for how they are formed. It would be appealing to have a mechanical way of calling turning points in realtime using only data produced by statistical agencies, or using only financial variables. Like Hamilton (2011), we find that it is very hard to do this within a parametric framework much faster than the NBER business cycle dating committee.

\subsection{The Challenges Ahead}

The previous two subsections suggest that the changing origins of the business cycle helps explain the episodic performance of conditionally homoskedastic forecasting models with time invariant parameters. The shortcomings also provide guides as to how forecasts and monitoring be improved. 
In terms of methodology, the financial crisis highlights the need to model parameter instability. There is some evidence that the performance of combination forecasts may be more stable than that of individual forecasts (Stock and Watson, 2003b). Also, volatility clustering is no longer a feature that macroeconomists can ignore. But efficient estimation of volatility model typically requires a larger number of observations than are available for macroeconomic analysis.

More generally, variation in financial time series occurs at frequencies much higher than those at which real activity variables are measured. Important contributions have been made to the task of analyzing data at different frequencies by Andreou, Ghysels, and Kourtellos (2013) and Auroba, Diebold, and Scotti (2009) and this is an active area of research.

The choice of variables used for forecasting is closely related to parameter instability. As a result of the gradual shift from traditional to shadow banking and for other reasons, conventional measures of the money supply no longer bear a simple relation with economic activity. New measures of money have been proposed, such as MZM - money-at-zero-maturity - to measure the supply of financial assets that are redeemable at par and on demand, including items such as money-market mutual funds. There is some evidence that MZM bears a more stable relationship with economic activity and interest rates (Teles and Zhou, 2005). Nonetheless, while MZM data are available since 1959, they are rarely used in academic research. MZM does not include repurchase agreements - and there is currently no official measure of the US money supply that does so.

While it is now clear that financial instability can have serious real consequences, we do not yet have a robust measure of financial stability, which impedes our ability to monitor it. Financial stability depends among other things, on asset and liability positions, measures of credit, leverage at both the household and firm level, and in a shadow banking environment, the length of rehypothetication chain. As pointed out in Adrian and Shin (2010), financial intermediaries balance sheet quantities reflect capital market conditions and thus the state of the economy. Yet data on the shadow banking system have been hard for researchers or even regulators to obtain. At a practical level, measuring the flow of credit during the most intense part of the crisis is tricky. For example, firms drew down their contractual lines of credit, in precautionary demand for liquidity, and banks had difficulty securitizing loans, and had to keep them on their balance sheets. For a while, such effects made aggregate lending appear to be increasing despite the evident panic in financial markets. Cohen-Cole, Duygan-Bump, Fillat, and Montoriol-Garriga (2008) give a very comprehensive discussion of the issues, as seen in the fall of 2008.

A different data challenge, emphasized by Gorton (2012), is that obtaining a reasonable sample size means using data going a long way back. The Great Depression is the closest 
precedent for the Great Recession (especially given the global nature of both of these events), but the structure of the economy has of course changed massively since the 1930s. Data from a long time ago may not be a good guide to what we should expect going forward. Also, government responses to crises make disentangling causality difficult.

\section{Implications for Identification Analysis}

The exercise of disentangling the sources of business cycles would be challenging even if recessions all had the same origins because the impulse and propagating mechanism of shocks cannot be separately identified from the data without additional assumptions, and validation of the assumptions is difficult when the true propagating mechanisms are never observed. The episodic nature of recessions makes such an exercise even more difficult.

A broad approach to understanding business cycle dynamics is to write down a (partial or general) equilibrium model that specifies the complete environment in which decisions of households and firms are made. Because models with too many features are computationally demanding, researchers tend to focus on features directly related to the problem of interest while leaving many aspects of the economy unspecified. The cost of starting from microfoundations is that equilibrium models do not encompass the details found in models of the Cowles foundation type. As is true of all identification analysis, the dynamic responses of structural models necessarily reflect the assumptions imposed. Often, the fit and forecasting properties of these models are not well understood. The ability of equilibrium models to recover the true propagating mechanisms rests on correct specification of the economic model and probably has less to do with econometric methods per se.

An alternative is a limited information approach that identifies the responses of interest from a reduced form model such as a vector-autoregression (VAR) that fits the data well. A VAR for $N$ covariance stationary series collected into a $N \times 1$ vector $X_{t}$ is defined by a system of linear equations $A(L) X_{t}=u_{t}$ where in the most basic form, $u_{t} \sim(0, \Omega)$ is a $N \times 1$ vector of homoskedastic white noise errors and the parameters in $A(L)$ are time invariant. Invertibility is imposed to yield the Wold moving-average representation $X_{t}=\psi(L) u_{t}$, where $\psi(L)$ is a one-sided polynomial in positive powers of the lag operator $L$. As we can premultiply $u_{t}$ and post-multiply $\psi(L)$ by any $N \times N$ non-invertible matrix $H$, the impulse and the propagating mechanism are not separately identifiable. Assumptions are needed to pin down a specific $H$ so that $\epsilon_{t}=H u_{t}$ can be given the desired structural interpretation.

VARs are widely used, because under covariance stationarity and invertibility, the Wold representation provides the best linear approximation to the data. The identified impulse responses often 'make sense' without fully specifying an economic model. Much work has 
been done in recent years to try to extend the VAR framework in important new directions:

(i) Time varying parameters (VAR-TVP) and stochastic volatility (VAR-SV) incorporated into VARs in part to address the debate as to whether the Great Moderation was a consequence of a reduction in the volatility of shocks versus a change in the propagation mechanism (Sims and Zha, 2006; Cogley and Sargent, 2005; Primiceri, 2005; Giannone, Lenza, and Reichlin, 2008; Gali and Gambetti, 2009). These extensions allow the $H$ matrix to be time varying.

(ii) There is a concern that the invertibility assumption restricts identification to primitive shocks that can be mapped to the innovations of the VAR. This precludes models with more complex information structures that frustrate the mapping from the structural shocks to $u_{t}$, and hence is not suited for analyzing shocks that are known by agents ahead of time (Leeper, Walker, and Yang, 2013). A related issue is that variables excluded from the system are assumed to be weakly exogenous for the parameters of interest. Because VARs are exactly identified, the exogeneity assumption is difficult to validate beyond adding or dropping a variable to check for robustness. Both problems can be alleviated, at least in theory, by letting $N$ be large. This reduces the possibility of omitted variables, and also make it less likely for the problem of non-fundamentalness to arise, Forni, Giannone, Lippi, and Reichlin (2009). However, large VARs are not feasible to estimate given a finite number of time series observations. The dimension of the problem can be reduced if $X_{t}$ has a factor structure, as considered in (1). Assuming that the $r$ common factors have dynamics characterized by $\Phi(L) F_{t}=\eta_{t}$, it is easy to see that the augmented system consisting of $X_{t}$ and $F_{t}$ is still a VAR. The factor augmented VAR (FAVAR) implies a moving average representation:

$$
X_{t}=\psi_{1}(L) \eta_{t}+\psi_{2}(L) e_{t}
$$

Identification now requires specification of a $N \times r$ matrix to rotate $\eta_{t}$ to the structural common shocks $\epsilon_{t}$ The $u_{t}$ in a VAR in $X_{t}$ is a linear combination of the innovations in a FAVAR. The appeal of the FAVAR is that it allows the effects of common shocks to be analyzed while keeping the dimension of the system small. FAVARs have been used to understand the transmission mechanism of monetary policy (Bernanke and Boivin, 2003).

The VAR-TVP, VAR-SV and FAVAR models all admit linear state space representations, just like the basic VAR. Identification analysis still boils down to imposing assumptions on $H$. A natural question to ask is whether a VAR or its extended variants are appropriate 
for business cycle analysis when recessions are episodic. The magnitude and breadth of the Great Recession gives us some reasons to suspect that it cannot readily be accommodated within a linear state space framework:

(i) It is questionable whether the same variables can be used to analyze non-financial and financial recessions alike. The balance sheet effect which was crucial in explaining the Great Recession may not be well identified because there is only one such large episode in the post-war sample. Furthermore, data on credit-worthiness of firms and households are not available for a very long time span.

(ii) With unprecedented events like the Lehman collapse, and the growing importance of shadow banking, the possibility of new common shocks is real. Increased global linkages may also require consideration of new shocks. Some evidence indicates that $r$ is not constant over time. According to the $I_{2}$ criterion, there are seven factors in the full sample spanning 1960 to 2011, but there are 5, 8 and 3 in the 1960-1983, 1984-2006 and 2007-2011 subsamples, respectively. Bai and Ng (2007) report further evidence on the sensitivity of the number of factors to the sample period, using dynamic factors. However, FAVAR analysis does not yet allow the number of common shocks $r$ to be time-varying: there is no room for shocks to 'pop' in and out of the VAR.

(iii) The data used in VARs are often detrended in a way that prohibits low frequency variations from interacting with the ones at business cycle frequencies. For example, HP filtered data $X_{t}$ are obtained by applying a two-sided filter $B(L)$ with constant parameters to observed data, say, $Y_{t}$. If the secular trends are responsible for the Great Moderation and the slow recovery from the Great Recession as has been suggested, we may need the coefficients in $B(L)$ to vary in a way that reflect the secular changes. Restraining the coefficients to be constant would inadvertently constrain the propagating mechanisms we uncover.

In a sense, the issues relate to the fact that while the Wold representation seems appropriate for analyzing small shocks in a stationary environment, it is no longer optimal in any particular sense when the data are not covariance stationary. Furthermore, a linear characterization may be inadequate when the data exhibit features like the Great Recession. For example, fiscal multipliers may be greater at the zero lower bound than in normal times. ${ }^{22}$ The ZLB is itself a form of non-linearity. But the length of time that the US economy has been stuck in this liquidity trap is happily still too short for conventional macroeconomic

\footnotetext{
${ }^{22}$ See for example Eggertson and Woodford (2003), Woodford (2011) and Christiano, Eichenbaum, and Rebelo (2011).
} 
time series analysis. Most existing macroeconomic, finance, and term structure models simply ignore the non-linearity induced by ZLB.

\subsection{Non-linearities and Identification}

Numerous models suggest the possibility of non-linear dynamics in business cycles. Indeed, the fact that the univariate properties of output growth are well characterized by a two-state Markov switching model (Hamilton, 1989), as discussed above, is evidence for some reduced form nonlinearity. Still, beyond this, there is little empirical evidence for non-linearity in aggregate data. The idea that small shocks can sometimes have outsized effects, which is central to the financial accelerator mechanism, does not show up clearly in aggregate time series data. The difficulty from an identification standpoint is that non-linearities at the firm and household level may not survive aggregation. To illustrate this point, we simulate data from four models each with two factors as follows:

$$
\begin{aligned}
& \text { Model 1 } X_{i t}=\lambda_{i 1} F_{1 t}+\lambda_{i 2} F_{2 t}+e_{i t} \\
& \text { Model 2 } X_{i t}=\lambda_{i 1} F_{1 t}+\lambda_{i 2} F_{2 t}+\gamma_{i} 1_{F_{1 t-1}<=-.2}+e_{i t} \\
& \text { Model 3 } X_{i t}=\left(\lambda_{i 1}+\gamma_{i t}\right) F_{1 t}+\lambda_{i 2} F_{2 t}+e_{i t} \\
& \text { Model 4 } X_{i t}=\lambda_{i 1} F_{1 t}+\lambda_{i 2} F_{2 t}+\gamma_{i} F_{t-1} F_{t-2}+e_{i t}
\end{aligned}
$$

where in each case, $F_{j t}=\rho_{j}^{F} F_{j t-1}+\eta_{j t}$ with $\rho_{1}^{F}=.8$ and $\rho_{2}^{F}=.5$. For each $i=1, \ldots N$, $u_{i t}=\rho_{i} u_{i t-1}+w_{i t}$ with $\rho_{i} \sim[0,8], \lambda_{i} \sim N(0,1), \gamma_{i} \sim U[0,1]$ and $\gamma_{i t} \sim U[0,1]$. The shocks $e_{i t}$ and $\eta_{j t}$ are iid $\mathrm{N}(0,1)$ and mutually uncorrelated.

The benchmark is Model 1, which is linear in the factors. In Model 2, the effect of a shock to the first common factor depends on $F_{1 t-1}$. Model 3 introduces time variation in the loadings on the first factor. Model 4 allows for a multiplicative interaction between the two factors. The $I C_{2}$ criterion of Bai and $\mathrm{Ng}$ (2002) correctly indicates two factors in models 1 and 3 , but three factors in models 2 and 4 . Omitted non-linearity can lead to spurious additional factors.

The effect of a shock to $F_{1}$ is obtained by computing the generalized impulse response averaged over 100 different starting values. These responses, shown as the solid blue line in Figure 3, are computed using the true parameters and factors, and no estimation is involved. To see how well a linear model approximates the true dynamic responses, two sets of responses are computed. The first estimates a linear VAR in $X_{i t}, F_{1 t}, F_{2 t}$ for each $i$ and then average the responses over $i$. This is shown as the dotted red line. The second method aggregates $X_{i t}$ into $\bar{X}_{t}$ and impulse responses are obtained from a VAR in $\left(\bar{X}_{t}, F_{1 t}, F_{2 t}\right)$. This 
is shown as the black line.

For each of the four non-linear models considered, it is easy to find cases where the linear response for some $i$ is very far from the series specific non-linear response. But what about the aggregate response? The top left panel for model 1 shows that the linear VAR closely approximates the true responses when the true model has no non-linear dynamics. For model 2 , the top right panel shows that the linear model gives a smoother response but estimates the shape of the response function quite well. The bottom left panel shows that in spite of omitted time variation in the loadings in model 3, the actual response is well approximated by the linear model. For model 4 , the linear VAR underestimates the true response at impact significantly but the adjustment path is close to the true after four periods.

\section{Figure 3: VAR and Non-Linearity}
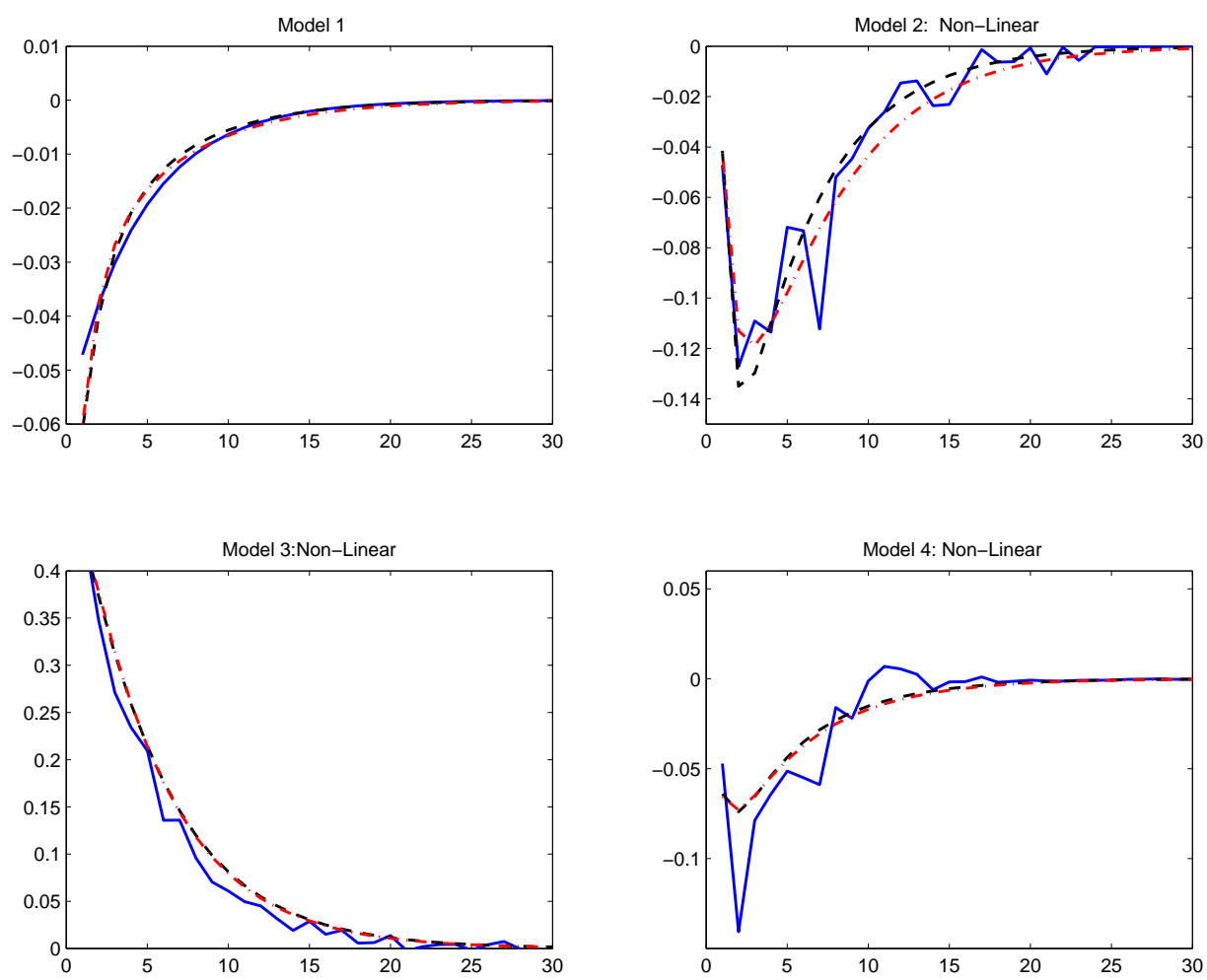

Notes: For each of the four model specifications discussed in the text, the plot shows the true nonlinear generalized impulse responses (blue solid line), the average disaggregated linear impulse responses (red dots) and the aggregated linear impulse responses (black dashed line).

Overall, the linear VAR is not doing a bad job approximating the true responses in spite of omitted non-linearity. It does not matter whether we aggregate the individual response 
or aggregate the data. Of course, the results are specific to the parameterizations chosen. The point is that even if non-linear dynamics are at work, a linear VAR may approximate the propagating mechanism reasonably well, though the correct non-linear model will do better. Consequently it is very hard to identify the non-linearity from aggregate data alone. This goes back to our earlier remark that if certain variables are omitted and/or the number of factors is incorrectly specified, the identification ability of linear models can be severely compromised. Finding the right variables for analysis is at least as important as finding the correct functional form.

Non-linearity is an important part of the theories that attempt to explain the Great Recession with a financial accelerator mechanism along the lines of Bernanke, Gertler, and Gilchrist (1996). Given the size of the subprime mortgage market relative to the global economic system, the Great Recession seems a classic case of a modest initial impulse having an outsized effect. It would be reassuring if the data provided evidence for non-linearity in support of the theories. Stock and Watson (2012) fit a dynamic model with six common factors to 198 quarterly time series in US postwar data to disentangle the channels of the Great Recession. They find no non-linearity or structural break in the parameters of this dynamic factor model. They conclude that the Great Recession owes mainly to particularly large shocks to the financial and uncertainty factors, but the dynamic effect of those shocks on the economy was largely the same as in earlier business cycles. This suggests that the Great Recession is similar to other recessions, just bigger, at least from the perspective of a dynamic factor model fitted to quarterly aggregate data. This finding may well be a consequence of our limited ability to identify non-linear effects in aggregate data with the econometric tools at hand, as our simulation exercise illustrates. In this regard, it is notable that Sims (2012) considered a 6-variable VAR in monthly data and found that in the last 3 months of 2008 and the first half of 2009, the residuals were large in magnitude and oscillating in sign ${ }^{23}$. Thus large shocks were not simply feeding through the unchanged propagation mechanism. The quarterly data of Stock and Watson (2012) may be too low a frequency to see this. Higher frequency data, more disaggregated data, or new econometric tools may help uncover clearer evidence of non-linearity.

\section{Conclusions}

In this paper, we have updated some of the business cycle facts characterized by Zarnowitz (1985). There have been important developments in the economy since then. One is the

\footnotetext{
${ }^{23}$ The VAR was estimated on data through September 2007 and then out-of-sample residuals were computed.
} 
reduction in volatility known as the Great Moderation. That decline in volatility was endedor at least interrupted - by the Great Recession. All the recessions since the mid 1980s have had financial origins, although the 1990-1991 and 2001 recessions were mild and brief. The last three recessions have been characterized by slow and jobless recoveries, unlike the rapid bouncebacks from earlier downturns. Productivity appears to have become somewhat less procyclical. Examining business cycles over many countries and over a long time period, most researchers find that recoveries from recessions with financial-market origins are systematically different, and slower. There have also been important econometric developments since Zarnowitz wrote, including models with time-varying parameters, regime switching models and the use of factor analysis to incorporate the information from a large panel of data. We have used these new tools.

There is an apparent lack of encompassing - forecasting and economic models that can explain the facts uniformly well across business cycles. This is perhaps an inevitable outcome given the changing nature of business cycles. The fact that business cycles are not all alike naturally means that variables that predict activity have a performance that is episodic. Notably, we find that term spreads were good predictors of economic activity in the 1970s and 1980s, but that credit spreads have fared better more recently. This is of course a challenge for forecasters, as we do not know the origins of future business cycle fluctuations. Much needs to be learned to determine which and how financial variables are to be monitored in real time especially in an evolving economy when historical data do not provide adequate guidance.

Explanations for the Great Recessions usually involve some form of non-linearity. The sudden nature of the downturn following the collapse of Lehman is consistent with nonlinearity being part of the transmission mechanism. At the same time, we lack robust evidence of non-linearity from aggregate low-frequency macroeconomic data. Essentially, there is an identification issue as different structural models can fit aggregate macroeconomic data about equally well. Breaking this observational equivalence, by looking at higherfrequency or more disaggregated data, is the cutting edge of business cycle research. 


\section{References}

Adrian, T., And H. S. Shin (2009): "Prices and Quantities in the Monetary Policy Transmission," International Journal of Central Banking, pp. 131-142. (2010): "Financial Intemediaries and Monetary Economics," Handbook of Monetary Economics, Chapter 12, 601-650.

(2012): "Which Financial Frictions? Parsing the Evidence from the Financial Crisis of 2007-2009," in NBER Macroeconomics Annual, vol. 27. National Bureau of Economic Research.

An, S., And F. Schorfheide (2007): "Bayesian Analysis of DSGE Models," Econometric Reviews, 26: 2-4, 113-172.

Andersen, T., T. Bollerslev, P. Christoffersen, and F. Diebold (2012): "Financial Risk Measurement for Financial Risk Management," in Handbook of the Economics of Finance, ed. by G. Constantinedes, M. Harris, and R. Stultz, vol. forthcoming.

Andreou, E., E. Ghysels, and A. Kourtellos (2013): "Should Macroeconomic Forecasters use Daily Financial Data and how?," Journal of Business and Economic Statistics, $31,240-251$.

Aruoba, S. B., and F. X. Diebold (2010): "Real-Time Macroeconomic Monitoring: Real Activity, Inflation and Interactions," American Economic Review, 100, 20-24.

Auroba, S., F. Diebold, and C. Scotti (2009): "Real-Time Measurement of Business Conditions," Journal of Business and Economic Statistics, 27(4), 417-27.

Bachmann, R., and G. Moscarini (2011): "Business Cycles and Endogenous Uncertainty," Working Paper, Yale University.

BAI, J., AND S. NG (2002): "Determining the Number of Factors in Approximate Factor Models," Econometrica, 70:1, 191-221.

BAI, J., AND S. NG (2007): "Determining the Number of Primitive Shocks in Factor Models," Journal of Business and Economic Statistics, 25, 52-60.

BAI, J., And S. NG (2008): "Large Dimensional Factor Analysis," Foundations and Trends in Econometrics, 3:2, 89-163.

Bansal, R., D. Kiku, and A. Yaron (2010): "Long Run Risks, the Macroeconomy, and Asset Prices," American Economic Review: Papers and Proceedings, 100(2), 1-5.

Bansal, R., and A. Yaron (2004): "Risks for the Long Run: A Potential Resolution of Asset Pricing Puzzles," Journal of Finance, 59, 1481-1509.

BArro, R. (2006): "Rare Disasters and Asset Markets in the Twentieth Century," Quarterly Journal of Economics, 12(3), 823-866.

BASU, S., AND B. Bundick (2012): "Uncertainty Shocks in a Model of Effective Demand," working paper. 
Basu, S., And J. Fernald (2001): "Why is Productivity Procyclical? Why do We Care?," in New Developments in Productivity Analysis, ed. by E. R. D. Charles R. Hulten, and M. J. Harper, pp. 225-302. National Bureau of Economic Research, University of Chicago Press.

Basu, S. B., J. Fernald, and M. Kimball (2006): "Are Technology Improvements Contractionary?," American Economic Review, 96, 1418-1448.

Bernanke, B., And J. Boivin (2003): "Monetary Policy in a Data Rich Environment," Journal of Monetary Economics, 50:3, 525-546.

Bernanke, B. S., and M. Gertler (1989): "Agency Costs, Net Worth, and Business Fluctuations," American Economic Review, 79, 14-31.

Bernanke, B. S., M. Gertler, and S. Gilchrist (1996): "The Financial Accelerator and Flight to Quality," Review of Economics and Statistics, 78(1), 1-15.

- (1999): "The Financial Accelerator in a Quantitative Business Cycle Framework," in Handbook of Macroeconomics, Vol. 1C, ed. by J. B. Taylor, and M. Woodford. Elsevier.

Beveridge, W. (1944): Full Employment in a Free Society. George Allen and Unwin, London.

Blanchard, O. J. (1997): "The Medium Run," Brookings Paper on Economic Activity, $2,89-158$.

Blanchard, O. J., and M. W. Watson (1986): "Are Business Cycles All Alike," in The American Business Cycle: Continuity and Change, ed. by R. J. Gordon, pp. 123-180.

Bloom, N. (2009): "The Impact of Uncertainty Shocks," Econometrica, 77, 623-685.

Bloom, N., M. Floetotto, N. Jaimovich, I. Saporta, and S. Terry (2012): "Really Uncertain Business Cycles," NBER Working Paper 18245.

Bordo, M. D., And J. G. Haubrich (2010): "Credit Crises, Money and Contractions: An Historical View," Journal of Monetary Economics, 57, 1-18.

(2012): "Deep Recessions, Fast Recoveries, and Financial Crises: Evidence from the American Record," Federal Reserve Bank of Cleveland Working Paper 12-14.

Brunnermeier, M. K., T. M. Eisenbach, and Y. Sannikov (2012): "Macroeconomics with Financial Frictions: A Survey," mimeo, Princeton University.

Brunnermeier, M. K., and Y. Sannikov (2013): "A Macroeconomic Model with a Financial Sector," American Economic Review, forthcoming.

Burns, A. F., And W. C. Mitchell (1946): Measuring Business Cycle. National Bureau of Economic Research, New York.

Canova, F. (1998): "Detrending and Business Cycle Facts," Journal of Monetary Economics, 41, 475-512.

Chauvet, M., and J. D. Hamilton (2006): "Dating Business Cycle Turning Points," in Nonlinear Time Series Analysis of Business Cycles, ed. by P. R. Costas Milas, and D. van Dijk, Amsterdam. Elsevier. 
Chauvet, M., and J. Piger (2008): "A Comparison of the Real-Time Performance of Business Cycle Dating Methods," Journal of Business and Economic Statistics, 26, 42-49.

Chodorow-Reich, G. (2013): "The Employment Effects of Credit Market Disruptions: Firm-level Evidence from the 2008-09 Financial Crisis," working paper.

Christiano, Lawrence, J., and T. J. Fitzgerald (1998): "The Business Cycle: It is Still a Puzzle," Economic Perspective, Federal Reserve Bank of Chicago, 22:4, 55-83.

Christiano, L. J., M. Eichenbaum, and S. Rebelo (2011): "When is the Government Spending Multiplier Large?," Journal of Political Economy, 119, 78-121.

Cogley, T., and T. J. Sargent (2005): "Drifts and Volatilities: Monetary Policies and Outcomes in the Post World War II U.S," Review of Economic Dynamics, 8, 262-302.

Cohen-Cole, E., B. Duygan-Bump, J. Fillat, and J. Montoriol-Garriga (2008): "Looking Behind the Aggregates: A Reply to 'Facts and Myths About the Financial Crisis of 2008'" Federal Reserve Bank of Boston Working Paper No. QAU08-5.

Comin, D., And M. Gertler (2006): "Medium Term Business Cycles," American Economic Review, 96(3), 523-551.

Croushore, D. (2011): "Frontiers of Real-Time Data Analysis," Journal of Economic Literature, 49, 72-100.

Daly, M. C., B. Hobijn, A. Sahin, and R. G. Valletta (2012): "A Search and Matching Approach to Labor Markets: Did the Natural Rate of Unemployment Rise?," Journal of Economic Perspectives, 26, 3-26.

Davis, S. J., And J. A. Kahn (2008): "Interpreting the Great Moderation: Changes in the Volatility of Economic Activity at the Macro and Micro Levels," Journal of Economic Perspectives, 22, 155-180.

Devereux, M. B., And J. Yetman (2010): "Leverage Constraints and the International Transmission of Shocks," Journal of Money Credit and Banking, 42, 71-105.

Diebold, F. X., And G. D. Rudebusch (1996): "Measuring Business Cycles: A Modern Perspective," Review of Economics and Statistics, 78, 67-77.

versity Press.

Doyle, B. M., and J. Faust (2005): "Breaks In the Variability and Comovement of G-7 Economic Growth," Review of Economics and Statistics, 87, 721-740.

Eggertson, G. B., And M. Woodford (2003): "The Zero Bound on Interest Rates and Optimal Monetary Policy," Brookings Papers on Economic Activity, 1, 139-211.

Erceg, C. J., and A. T. Levin (2013): "Labor Force Participation and Monetary Policy in the Wake of the Great Recession," working paper.

Estevão, M., and E. Tsounta (2011): "Has the Great Recession Raised U.S. Structural Unemployment?"," International Monetary Fund Working Paper 11/105.

Evans, M. D. (2005): "Where Are We Now? Real-Time Estimates of the Macroeconomy," International Journal of Central Banking, 1, 126-175. 
Faust, J., S. G. Gilchrist, J. H. Wright, and E. Zakrajsek (2013): "Credit Spreads as Predictors of Real-Time Economic Activity: A Bayesian Model-Averaging Approach," Review of Economic Statistics, forthcoming.

Faust, J., and J. H. Wright (2009): "Comparing Greenbook and Reduced Form Forecasts Using a Large Real-time Dataset," Journal of Business and Economic Statistics, 27, $468-479$.

Fernández-Villaverde, J. (2010): "The Econometrics of DSGE Models," SERIEs, 1, 3-49.

Fernández-Villaverde, J., P. Guerrón-Quintana, K. Kuester, and J. RubioRAMíREz (2012): "Fiscal Volatility Shocks and Economic Activity," working paper.

Fisher, I. (1933): "The Debt-Deflation Theory of Great Depressions," Econometrica, 1(4), $337-357$.

Forni, M., D. Giannone, M. Lippi, and L. Reichlin (2009): "Opening the Black Box: Identifying Shocks and Propogation Mechanisms in VAR and Factor Models," Econometric Theory, 25, 1319-1347.

Forni, M., M. Hallin, M. Lippi, and L. Reichlin (2000): "The Generalized Dynamic Factor Model: Identification and Estimation," Review of Economics and Statistics, 82:4, $540-554$.

Friedman, M. (1969): "The Optimum Quantity of Money and Other Essays," in Monetary Studies of the National Bureau, pp. 261-284, Aldine. Chicago.

Friedman, M. (1993): "The Plucking Model of Business Fluctuations Revisted," Economic Inquiry, 31:2, 171-177.

Frisch, R. (1933): "Propagation Problems and Impulse Responses in Dynamic Economics," in Essays in Honor of Gustave Cassel, London. George Allen.

Gali, J., And L. Gambetti (2009): "On the Sources of the Great Moderation," American Economic Journal: Macroeconomics, 1, 26-58.

Gali, J., And T. van Rens (2010): "The Vanishing Procyclicality of Labor Productivity," working paper.

Giacomini, R., And B. Rossi (2010): "Forecast Comparisons in Unstable Environments," Journal of Applied Econometrics, 25, 595-620.

Giacomini, R., and H. White (2006): "Tests of Conditional Predictive Ability," Econometrica, 74, 1545-1578.

Giannone, D., M. Lenza, and L. Reichlin (2008): "Explaining the Great Moderation: It is not the Shocks," Journal of the European Economic Association, 6, 621-633.

Giannone, D., L. Reichlin, and D. Small (2008): "Nowcasting GDP: The Real Time Informational Content of Macroeconomic Data Releases," Journal of Monetary Economics, $55,665-676$.

Gilchrist, S. G., V. Yankov, and E. Zakrajsek (2008): "Credit Market Shocks and Economic Fluctuations: Evidence from Corporate Bond and Stock Markets," Journal of Monetary Economics, 56, 471-493. 
Gilchrist, S. G., And E. Zakrajsek (2012): "Credit Spreads and Business Cycle Fluctuations," American Economic Review, 102, 1692-1720.

Gorton, G. (2012): "Some Reflections on the Recent Financial Crisis," NBER working Paper 18397.

Gorton, G., and A. Metrick (2012): "Getting Up to Speed on the Financial Crisis: A One-Weekend-Reader's Guide," Journal of Economic Literature, 50, 128-150.

Gourio, F. (2012): "Disaster Risk and Business Cycles," American Economic Review, $102(6), 2734-66$.

Guerrieri, V., and G. Lorenzoni (2011): "Credit Crises, Precautionary Savings, and the Liquidity Trap," NBER Working Paper 17583.

Hall, R. E. (2011): "The Long Slump," American Economic Review, pp. 431-469.

Hamilton, J. D. (1989): "A New Approach to the Economic Analysis of Nonstationary Time Series and the Business Cycle," Econometrica, 57, 357-384.

(1995): "What's Real About the Business Cycle," Federal Reserve Bank of St. Louis Review, 87, 435-52.

- (2011): "Calling Recessions in Real Time," International Journal of Forecasting, $27,1006-1026$.

Harding, D., And A. Pagan (2006): "Synchronization of Cycles," Journal of Econometrics, 132, 59-79.

Imbs, J. (2010): "The First Global Recession in Decades," IMF Economic Review, 58, 327-354.

Jorda, O., M. Schularick, And A. M. TAYlor (2011): "When Credit Bites Back: Leverage, Business Cycles, and Crises," Federal Reserve Bank of San Francisco working paper 2011-11.

Jurado, K., S. Ludvigson, and S. NG (2013): "Volatility or Uncertainty," mimeo.

KeEn, S. (1995): "Finance and Economic Breakdown: Modeling Minsky's 'Financial Instability Hypothesis'," Journal of Post Keynesian Economics, 4, 607-635.

Kim, C.-J., And C. Nelson (1999): "Has the U.S. Economy become more Stable? A Bayesian Approach Based on Markov Switching Model of the Business Cycle," Review of Economics and Statistics, 81(4), 608-616.

King, R. G., And M. Watson (1996): "Money, Prices, Interest Rates and the Business Cycle," Review of Economics and Statistics, 78:1, 35-53.

Kiyotaki, N., And J. Moore (1997): "Credit Cycles," Journal of Political Economy, 105, $211-248$.

Kose, M. A., C. Otrok, and C. H. Whiteman (2003): "International Business Cycles: World, Region, and Country Specific Factors," American Economic Review, 93.

Kroszner, R. S., L. Laeven, and D. Klingebiel (2007): "Banking Crises, Financial Dependence, and Growth," Journal of Financial Economics, 84, 187-228. 
Krugman, P. (2008): "The International Finance Multiplier," working paper.

Lane, P. R., and G. M. Milesi-Ferretti (2007): "The External Wealth of Nations Mark II: Revised and Extended Estimates of Foreign Assets and Liabilities, 1970-2004," Journal of International Economics, 73, 223-250.

Leeper, E., T. Walker, and S. Yang (2013): "Fiscal foresight: Analytics and Econometrics," Econometrica, forthcoming, NBER 14028.

LucAs, R. E. (1977): "Understanding Business Cycles," in Stabilization of the Domestic and International Economy, Carnegie-Rochester Conference Series on Public Policy, ed. by K. Brunner, and A. Meltzer. North Holland.

Ludvigson, S., And S. NG (2009): "Bond Risk Premia and Macro Factors," Review of Fiancial Studies.

McConnell, M., and G. Perez-Quiros (2000): "Output Fluctuations in the United States: What has Changed Since the Early 1980's?," American Economic Review, 90, $1464-1476$.

Mian, A., K. RaO, and A. Sufi (2011): "Household Balance Sheets, Consumption, and the Economic Slump," mimeo, University of Chicago.

Mian, A., And A. Sufi (2010): "Household Leverage and the Recession of 2007-09," IMF Economic Review, 58, 74-117.

(2012): "What Explains High Unemployment? The Aggregate Demand Channel," NBER working Paper 17830.

Minsky, H. P. (1986): Stabilizing an Unstable Economy. McGraw Hill, New York.

Nakamura, E., D. Sergeyev, and J. Steinsson (2012): "Growth-Rate and Uncertainty Shocks in Consumption: Cross-Country Evidence," NBER Working Paper 18128.

Nalewaik, J. J. (2011): "Forecasting Recessions Using Stall Speeds," Finance and Economics Discussion Series 2011-24, Federal Reserve Board, Washington.

Neftci, S. N. (1984): "Are Economic Time Series Asymmetric Over the Business Cycle," Journal of Political Economy, 92:2, 307-328.

NG, S. (2013): "Boosting Recessions," mimeo, Columbia University.

Pozsar, Z., T. Adrian, A. Ashcraft, and H. Boesky (2010): "Shadow Banking," Federal Reserve Bank of New York Staff Report 458.

Primiceri, G. E. (2005): "Time Varying Structural Vector Autoregressions and Monetary Policy," Review of Economic Studies, 72, 821-852.

Reifschneider, D., and J. C. Williams (2000): "Three Lessons for Monetary Policy in a Low-Inflation Era," Journal of Money Credit and Banking, 32, 932-966.

Reinhart, C. M., and K. S. Rogoff (2009a): "The Aftermath of Financial Crises," American Economic Review, 99, 466-72.

(2009b): This Time is Different: Eight Centuries of Financial Folly. Princeton University Press, Princeton. 

$1676-1706$.

(2011): "From Financial Crash to Debt Crisis," American Economic Review, 101, (2012): “Sorry, U.S. Recoveries Really Aren’t Different," Bloomberg Op-Ed.

Rossi, B., And T. Sekhposyan (2010): "Have Economic Models' Forecasting Performance for US Output Growth and Inflation Changed Over Time, and When?," International Journal of Forecasting, 26, 888-835.

Schularick, M., And A. M. TAYlor (2012): "Credit Booms gone Bust: Monetary Policy, Leverage Cycles and Financial Crises, 1870-2008," American Economic Review, $102,1029-1061$.

Sichel, D. E. (1994): "Inventories and the Three Phases of the Business Cycle," Journal of Business and Economic Statistics, 12, 269-277.

Sims, C. A. (2012): 'Discussion of 'Disentangling the Channels of the 2007-2009 Recession' (by Stock and Watson)," Brookings Papers on Economic Activity, 1, 141-148.

Sims, C. A., And T. Zha (2006): "Were there Regime Switches in US Monetary Policy?," American Economic Review, 96, 54-81.

SinAi, A. (1992): "Financial and Real Business Cycles," Eastern Economic Journal, 18:1, $1-54$.

Slutsky, E. (1937): "The Summation of Random Causes as the Sources of Cyclic Processes," Econometrica, 5, 105-146.

Stock, J. H., and M. W. Watson (1999): "Business Cycle Fluctuations in US Macroeconomic Time Series," in Handbook of Macroeconomics, ed. by J. B. Taylor, and M. Woodford. Elsevier.

Stock, J. H., and M. W. Watson (2002a): "Forecasting Using Principal Components from a Large Number of Predictors," Journal of the American Statistical Association, 97, $1167-1179$.

Stock, J. H., and M. W. Watson (2002b): "Has the Business Cycle Changed and Why?," NBER Macroeconomics Annual, 17, 159-230.

- (2003a): "Has the Business Cycle Changed? Evidence and Explanations," in Monetary Policy and Uncertainty, pp. 9-56. Federal Reserve Bank of Kansas City.

- (2003b): "Forecasting Output and Inflation: The Role of Asset Prices," Journal of Economic Literature, 41, 788-829.

Stock, J. H., and M. W. Watson (2005): "Implications of Dynamic Factor Models for VAR analysis," NBER WP 11467. Holland.

(2006): "Forecasting with Many Predictors," in Handbook of Forecasting. North

Stock, J. H., And M. W. Watson (2010): "Indicators for Dating Business Cycles: CrossHistory Selection and Comparisons," American Economic Review, 100, 16-19.

(2012): "Disentangling the Channels of the 2007-2009 Recession," Brookings Papers on Economic Activity, 1, 81-135. 
Teles, P., And R. Zhou (2005): "A Stable Money Demand: Looking for the Right Monetary Aggregate," Federal Reserve Bank of Chicago Economic Perspectives, pp. 50-63.

Tobin, J. (1972): "Inflation and Unemployment," American Economic Review, 62(1), 1-18.

Woodford, M. (2011): "Simple Analytics of the Government Expenditure Multiplier," American Economic Journal: Macroeconomics, 3, 1-35.

Zarnowitz, V. (1985): "Recent Work on Business Cycles In Historical Perspective," Journal of Economic Literature, 22:2, 523-580. 